PRODUTIVIDADES FLORESTAL E AGRÍCOLA EM SISTEMAS DE CULTIVO DA BRACATINGA (Mimosa scabrella Bentham) EM BOCAIÚVA DO SUL, REGIÃO METROPOLITANA DE CURITIBA PARANÁ

ODETE TEREZINHA BERTOL CARPANEZZI

Engenheira Agrônoma

FABIO POGGIANI

Orientador

Dissertação apresentada à Escola Superior de Agricultura "Luiz de Queiroz", da Universidade de São Paulo, para obtenção do Título de Mestre em Ciências - Área de concentração: Ciências Florestais.

\author{
PIR A C I C A B A \\ Estado de São Paulo - Brasil \\ Junho / 1994
}


Ficta catalografica preparada pela Geço de livros da

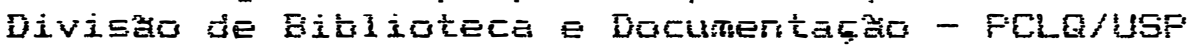

Darpanezzi, Bdete Terezintia Bertol

C274p Frodutividades trorestal e agricola en Eistemas de Cultivo da Fracatinga (Himosa sabrelia Eentham) em

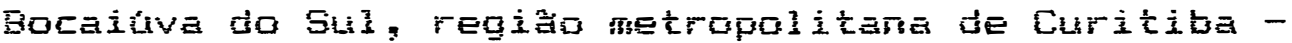
Faranta. Firacicata, 1974. $77 \mathrm{p}$.

Diss. (NEStre) - ESALQ

Eibliggrafia.

1. Agriculture - Fradutividade 2. Agrasei1vicultura 3. Bracetinga - Cultivo - Eocailua do Bul pF I. Escola Superigr de Agricultira Luiz de duesrog, Piracicata 
PRODUTIVIDADES FLORESTAL E AGRÍCOLA EM SISTEMAS DE CULTIVO DA BRACATINGA (Mimosa scabrella Bentham) EM BOCAIÚVA DO SUL, REGIÃO METROPOLITANA DE CURITIBA PARANÁ

ODETE TEREZINHA BERTOL CARPANEZZI

Aprovada em: 04/07/94

Comissão julgadora:

Prof. Dr. Fábio Poggiani

ESALQ/USP

Prof. Dr. Paulo Yoshio Kageyama

ESALQ/USP

Dr. Carlos Alberto Ferreira

EMBRAPA/CNPF

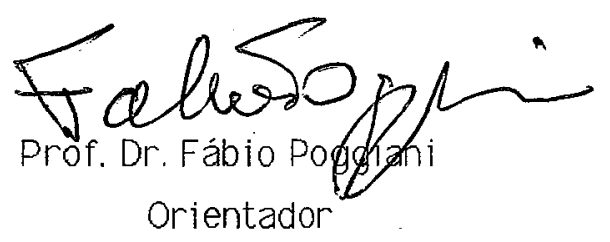




\section{SUMÁRIO}

\section{PÁGINA}

LISTA DE FIGURAS.

iv

LISTA DE TABELAS.

V

vii

RESUMO.

SUMMARY

ix

1. INTRODUÇÃO.

2. REVISÃO DE LITERATURA.

2.1. Definição e classificação de sistemas agrof lorestais.........

2.2. Principais sistemas silvoagricolas tradicionais

2.2.1. Pomares mistos ou hortas caseiras.

2.2.2. Agricultura migratória.

2.2.3. Sistema taungya.

2.3. O sistema tradicional de cultivo da bracatinga..

8

2.4. Características botânicas, ecológicas e silviculturais da bracatinga

2.4.1. Características botânicas.

2.4.2. Características ecológicas..

2.4.3. Caracteristicas silviculturais.

2.5. Culturas agricolas associadas à bracatinga..

3. MATERIAIS E MÉTODOS. 


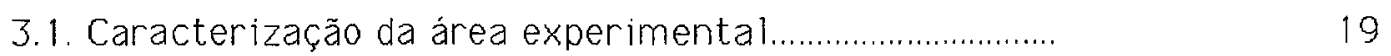

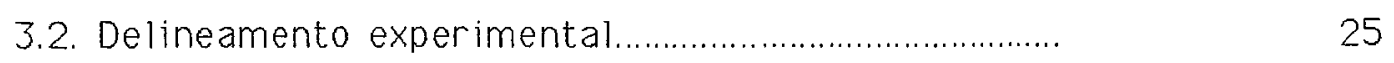

3.3. Implantação e condução do experimento.............................. 25

3.3.1. Implantação e condução da bracatinga.................... 26

3.3.2. Implantação e condução das culturas agrícolas...... 27

3.4. Predição do crescimento volumétrico da bracatinga......... 28

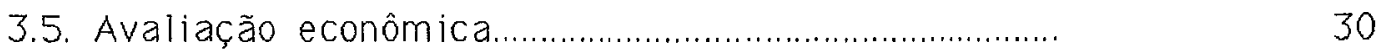

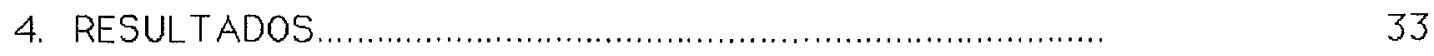

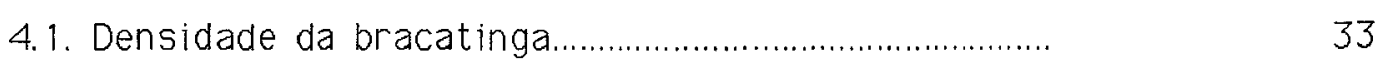

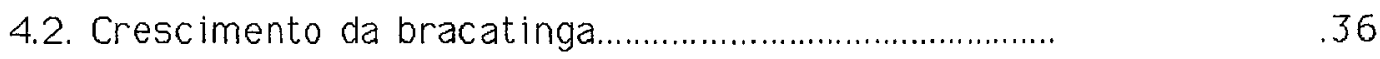

4.2.1. Crescimento em altura e diâmetro......................... 36

4.2.2. Crescimento em área basal e volume..................... 37

43. Equação para predição de crescimento volumétrico da bracatinga............................................................. 39

4.4. Rendimento das culturas agrícolas............................... 43

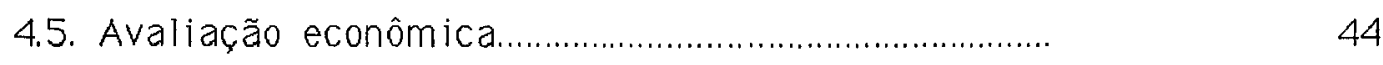

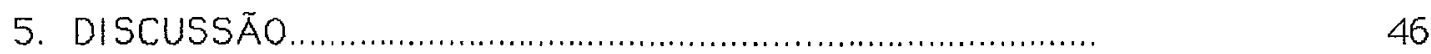

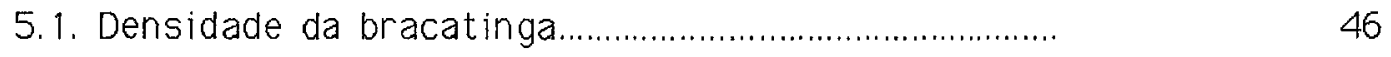

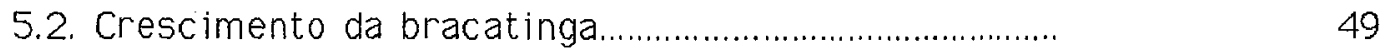

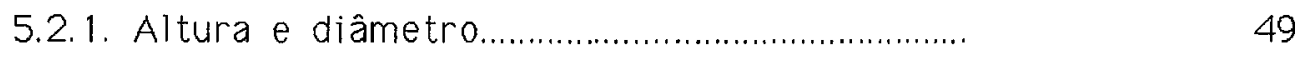

5.2.2. Volume individual........................................ 50 
5.2.3. Volume por hectare até os 29 meses de idade........

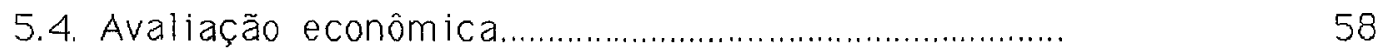

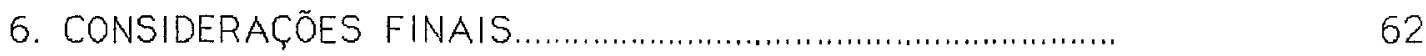

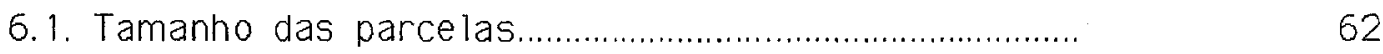

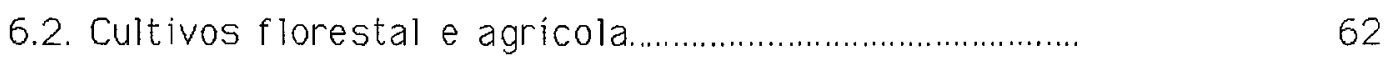

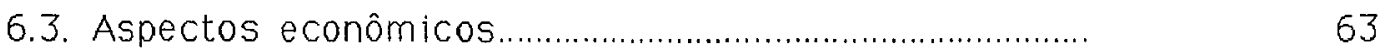

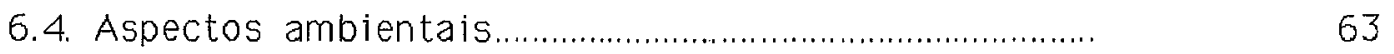

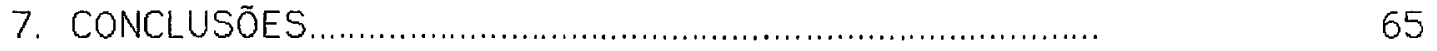

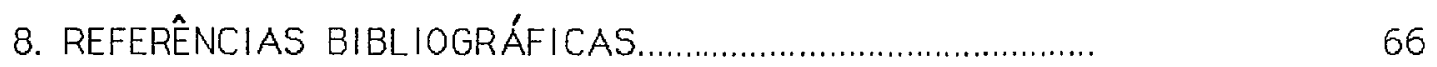




\section{LISTA DE FIGURAS}

PÁGINA

1. Principais fases do sistema agroflorestal tradicional do cultivo de bracatinga para produção de lenha

2. Localização geográfica da área experimental.

20

3. Precipitação mensal média de 10 anos e no periodo da experimentação Dados coletados no posto meteorológico do CNPF-EMBRAPA..

4. Número de plantas de bracatinga nascidas antes e após a primeira capina, por tratamento.

5. Evolução da densidade da bracatinga após a queima.

6. Evolução temporal de volume da bracatinga em função dos tratamentos....

7. Volume de bracatinga nos tratamentos, até os 7 anos de idade. 


\section{LISTA DE TABELAS}

PÁGINA

1. Características das espécies pioneiras, secundárias e climax..

2. Características de talhões de regeneração natural de bracatinga de diferentes idades, no Estado do Paraná. Arvores com DAP> a $5 \mathrm{~cm}$..

3. Precipitação e dias com chuva no ano agricola de implantação do expe-rimento $(1990 / 91)$

4. Dados de granulometria do solo do experimento. Amostras coletadas em outubro de 1990, após queima dos resíduos florestais.

5. Dados de análise quimica do solo do experimento. Amostras coletadas em outubro de 1990, após queima dos resíduos florestais

6. Localização, idade e espaçamento de bracatinga cujos volumes foram uti- lizados para determinação da equação de predição de volume.

7. Mão-de-obra utilizada em cada fase do sistema de cultivo da bracatinga...

8. Quantidade de insumos ( $\mathrm{Kg} / \mathrm{ha})$ utilizados nos tratamentos..

9. Preços no sistema de cultivo de bracatinga

10. Densidade da bracatinga antes e após desbaste aos 4 meses de idade e intensidade de desbaste. Média das parcelas dos tratamentos

11. Número de plantas de bracatinga aos 60 dias, nascidas antes e após a pri- meira capina.

12. Densidade da bracatinga aos 4, 15, 20 e 29 meses de idade. Média das parcelas... 
14. Diâmetro da bracatinga aos 4, 15, 20 e 29 meses de idade.

15. Area basal da bracatinga aos 4, 15, 20 e 29 meses de idade.

16. Volume cilindrico individual da bracatinga aos 15, 20 e 29 meses de - idade.

17. Volume cilíndrico por área da bracatinga aos 15, 20 e 29 meses de - idade.

18. Coeficientes "a" e "b" e coeficiente de determinação $R^{2}$ obtidos pela re- gressão $Y=a x^{b}$

19. Volumes sólidos em pé com casca previstos até os sete anos, calculados pela equação de predição desenvolvida.

20. Produção de lenha por hectare, aos sete anos de idade, calculada a par-tir da fórmula de predição de volume desenvolvida. Fator de empilha-mento $=1,75$

21. Produtividades de milho e feijão.

22. Valor Líquido Presente (VLP) para sistemas florestais e agroflorestais de bracatinga e plantio de milho com feijão. Taxas de desconto a $6,8 \mathrm{e}$ $10 \%$

23. Relação Benefício-Custo (RBC) e Taxa Interna de Retorno (TIR) para sistemas florestais e agrof lorestais da bracatinga e plantio de milho com feijão. Taxas de desconto de 6,8 e $10 \%$. 


\title{
PRODUTIVIDADES FLORESTAL E AGRÍCOLA EM SISTEMAS DE CULTIVO DA BRACATINGA (Mimosa scabrella Bentham) EM BOCAIÚVA DO SUL, REGIÃO METROPOLITANA DE CURITIBA - PARANÁ
}

\author{
Autora: ODETE TEREZINHA BERTOL CARPANEZZI \\ Orientador: FABIO POGGIANI
}

\section{RESUMO}

O sistema agroflorestal tradicional de cultivo da bracatinga (Mimosa scabrella Bentham) para produção de lenha existe desde o começo do século na Região Metropolitana de Curitiba - PR e abrange ho je cerca de 60 mil hectares. Trata-se de um sistema com produtividades agricola e florestal não elevadas, compensadas pelos niveis baixos de aplicação de insumos e de emprego de mão-de-obra, o que o torna economicamente atraente.

Conceitualmente, o sistema tradicional de cultivo da bracatinga é uma variação do sistema taungya. Ele é praticado, de modo predominante, em propriedades agrícolas de tamanhos pequeno e médio, e possui papéis econômico, social e ambiental importantes. Desde o seu início, as inovações tecnológicas no sistema, para aumento de produtividade, foram poucas e introduzidas diretamente pelos agricultores.

Visando melhorar o desempenho do sistema, um experimento de campo foi realizado em um bracatingal em Bocaiúva do Sul - PR, no início de uma rotação baseada em regeneração natural. Os tratamentos, ou sistemas de cultivo alternativos, consist iram em vários niveis de redução da densidade inicial da bracatinga, associados à mudanças na disposição espacial das culturas agrícolas e na sua adubação. Um tratamento somente com cultivos agrícolas foi incluido com o objetivo de estabelecer contraste com o sistema agroflorestal tradicional, o qual é a forma predominante de produção agrícola na região. 
Em todos os tratamentos, as culturas agricolas foram restritas ao primeiro ano. A bracatinga foi medida até a idade de 29 meses. A produção volumétrica da bracatinga, nos tratamentos, foi prevista até a idade de sete anos, por uma equação desenvolvida especialmente para isto. A avaliação econômica foi baseada nos volumes previstos aos sete anos.

Os resultados conduziram às seguintes conclusões: 1. a ausência de capinas é prejudicial ao crescimento da bracatinga, pelo acirramento das competições intra e interespecífica; 2 os cultivos agricolas intercalares tendem a prejudicar a produtividade florestal somente na fase inicial (até 15 meses de idade), comparativamente ao cultivo da bracatinga não consorciada com densidade similar; 3. a redução da densidade de plantas de bracatinga, em nivel mais acentuado do que ora praticado no sistema agroflorestal tradicional, implica em redução da mortalidade em valores absolutos e aumenta, consideravelmente, o crescimento individual das árvores; 4. para o aumento de produtividade de lenha por área, há necessidade de investigações complementares para precisar a densidade ideal de plantas de bracatinga e o momento de realizar o desbaste; 5 . a produtividade agricola é superior em sistemas não consorciados com bracatinga; e 6 . todos os sistemas de cultivo comparados são rentáve is do ponto de vista econômico; todavia, o escalonamento dos sistemas segundo a rentabil idade depende do critério econômico utilizado. 


\title{
PRODUCTIVITY OF AGROFORESTRY SYSTEMS WITH BRACATINGA (Mimosa scabrella Bentham) AT BOCAIUVA DO SUL, METROPOLITAN REGION OF CURITIBA - PARANÁ, SOUTHERN BRAZIL
}

\author{
Author: ODETE TEREZINHA BERTOL CARPANEZZI \\ Adviser: FABIO POGGIANI
}

\section{SUMMARY}

The agroforestry system with bracatinga (Mimosa scabrella Bentham) has been used for firewood production, in the Metropolitan Region of Curitiba, since the beginning of this century. It is estimated that 60,000 ha are now ocuppied by this traditional cultivation system in this Region. In despite of its low forestry and agricultural productivity, the system is economically atractive because of its low demand of labour and technology input.

The bracatinga agroforestry system is a variation of the taungya system. It is characterized by its short cicle, since it is based on the bracatinga's rotation (around seven years); after the second rotation, the bracatinga is regenerated naturally by seeds; and firewood is the main forest product obtained. The system is used mainly in small and medium farms and it represents an import ant economic, social and environmental role in the region. The few changes introduced in this system were made by its users.

A field experiment was carried out at Bocaiuva do Sul, PR, aiming to improve the productivity of this bracatinga agroforestry system. The trial was based on a natural regenerated stand of bracatinga. Alternative cultivation systems tested were constitued of several levels of initial population density of bracatinga, associated with different spatial distribution of agricultural crops and fertilization levels. A single 
agricultural crop was included as control. Evaluations of agricultural crops production were restricted to the first year, and bracatinga productions were evaluated up to the age of twenty nine months. Bracatinga production at seven years was estimated using a mathematic model specially developed for this study. An economic evaluation was carried out based on the productivity estimated for bracatinga at the age of seven years.

The following conclusions were obtained in this study: 1. bracatinga's growth was affected by inter- and intra-specif ic competition; 2 in the absence of weeds, the productivity of bracatinga was affected by agricultural crops but only in the initial phase (until 15 months); 3. bracatinga individual growth and survival rates were higher with lower populational density; 4. complementary investigations are needed to determine the ideal initial populational density and thinning age for bracatinga; 5. productivity rates of agricultutal crops were sign if icantly lower in the bracatinga agroforestry systems; 6 . all the systems analised showed positive rentability; however, the choice for the best option depends on the criteria adopted to estimate the rentability. 
Ao Adir Bandeira e a todos

os pequenos produtores de

bracatinga

Ao Fernandão que, com sua sensibilidade, me ensinou a entender e valorizar as pessoas e coisas simples. in memoriam

Para Toco, Xexéu e Mariana, companheiros em todos os momentos da realização deste trabaiho 


\section{AGRADECIMENTOS}

Ao Professor Paulo Y. Kageyama, pela amizade e colaboração na elaboração deste trabalho.

Ao professor Fabio Poggiani, pelas sugestões para o aprimoramento deste trabalho

A Adir Bandeira, proprietário da área onde foi realizada a pesquisa.

Aos pesquisadores Sergio Arhens, Paulo E. R. Carvalho e Antonio A. Carpanezzi, que forneceram dados de medições de bracatinga que possibilitaram a elaboração da equação de predição de volume.

Ao pesquisador Luiz Roberto Graça, pela orientação na fase inicial deste trabalho.

Ao pesquisador Carlos Alberto Ferreira, pela contribuição no desenvolvimento da equação de predição de volume.

A Augusto Haruki Nakao, pelo auxílio no processamento de dados para determinação da equação de predição de volume e para a avaỉiação econômica.

Aos pesquisadores Marcos F. G. Rachwal e Gustavo R. Curcio, pelo auxílio na caracterização dos solos.

A EMBRAPA-CNPF, pelo apoio aos trabalho de campo. 


\section{INTRODUÇÃO}

A bracatinga (Mimosa scabrella Bentham) é cultivada na Região Metropolitana de Curitiba, para produção de lenha, desde o inicio do século (HOEHNE, 1930; MARTINS, 1944). Ela compõe um sistema agroflorestal tradicional que ocupa, hoje, uma área aproximada de $60 \mathrm{mil} \mathrm{hectares} \mathrm{e} \mathrm{fornece,} \mathrm{anualmente,} \mathrm{mais} \mathrm{de} \mathrm{um}$ milhão de esteres de lenha e produtos alimentícios, principalmente, milho, feijão e mel (COPEL, 1985; LAURENT et al. 1990a).

No sistema tradicional de cultivo, a bracatinga é implantada juntamente com culturas agricolas, predominantemente, milho e feijão, restritas ao ano inicial. A implantação da bracatinga é por sementes e a exploração florestal ocorre, normalmente, aos sete ou oito anos, por corte raso. A segunda rotação e as seguintes são induzidas pela queima, que favorece a regeneração natural via sementes, ao mesmo tempo que prepara o terreno para o plantio das culturas agrícolas.

O sistema agrof lorestal da bracatinga é praticado em milhares de pequenas e médias propriedades agricolas, nas áreas de maior declividade. A baixa fertilidade do solo, aliada à pouca tecnologia empregada no sistema, resultam em baixas produtividades. Mesmo assim, o sistema tradicional constitui aos produtores rurais uma opção econômica de uso da terra. Nos mesmos ambientes, cultivos agricolas contínuos e a pecuária apresentam baixa rentabilidade e outras espécies florestais, como Pinus elliottii e Eucalyptus viminalis, têm baixos retôrnos econômicos, pelos altos custos de implantação e manutenção (GRAÇA et al., 1986; CARPANEZZ) et al., 1988).

O sistema agrof lorestal tradicional de cultivo da bracatinga, desde o seu início, apresentou poucos avanços tecnológicos, quer na implantação, quer na condução e manutenção das culturas agrícolas consorciadas. Esta situação ense ja a realização de investigações que conduzam ao seu melhoramento e impeçam a sua 
desestruturação, o que teria consequências indese jáveis dos pontos de vista social, econômico e ambiental.

Por outro lado, grandes consumidores regionais de lenha de bracatinga, especialmente indústrias de cal e cimento, interessam-se em produzi-la em grandes áreas cont inuas. Para isto, o sistema tradicional necessita ser parcialmente modificado, introduzindo-se práticas para a intensificação da produção florestal. Um sistema de produção exclusivamente florestal é interessante, também, para a introdução da bracatinga em outras regiões, visto que as práticas do sistema tradicional repousam em características históricas, naturais e sócio-econômicas locais.

O presente trabalho visou avaliar, experimentalmente, sistemas agrof lorestais e florestais modificados da bracatinga, introduzindo-se práticas de cultivo relativos a niveis de redução da densidade inicial da bracatinga e adubação, distribuição espacial e adensamento das culturas agrícolas. 


\section{REVISÃO DE LITERATURA}

\subsection{Definição e classificação de sistemas agroflorestais}

Segundo LAURENT (1990a) existem divergências sobre a noção de sistema, embora um sistema possa ser, genericamente, definido como um conjunto de elementos em interação dinâmica, organizado em função de seus ob jetivos ou metas. No que diz respeito ao desenvolvimento rural, o autor apresenta as seguintes def inições:

- Sistema agrário: é a expressão do funcionamento dos diferentes elementos do espaço agrícola. A escala de caracterização de um sistema agrário corresponde a uma microrregião homogênea. Esta caracterização não se limita a considerar o uso do solo e as atividades praticadas, mas abrange a interação do ecossistema com a organização do trabalho, e outros aspectos.

- Sistema de produção: é o conjunto estruturado das atividades agropecuárias praticadas em uma propriedade ou em um grupo de propriedades com padrão de uso da terra similar.

- Sistema de cultivo: é um componente do sistema de produção que enfoca a parcela ou o talhão dentro da propriedade, onde estão combinadas as espécies e variedades cultivadas, detalhando tecnologias, rendimentos, mane jo e práticas culturais adotadas.

Muitos autores têm elaborado definições que melhor expressem a agrossilvicultura. NAIR (1979) apresenta várias definições, elaboradas por diferentes autores, e após analisá-las, opta pela de LUNDGREN \& RAINTREE (1982). Segundo estes autores, agrossilvicultura ("agroforestry") é uma denominação coletiva para sistemas e tecnologias de uso da terra nos quais plantas lenhosas perenes (árvores, arbustos, palmeiras, bambus etc) são deliberadamente usadas, em um mesmo terreno, em consórcio com culturas agrícolas ou com animais, em alguma forma de arranjo 
espacial ou numa sequência temporal. Nos sistemas agrossilviculturais (sinônimo: sistemas agrof lorestais) existem interações ecológicas e interações econômicas entre os diferentes componentes.

Sistemas agroflorestais, estudados pela agrossilvicultura, podem ser definidos como: sistemas de cultivo nos quais espécies agrícolas e ou animais são cultivadas junto com espécies arbóreas, durante ou após a fase de estabelecimento destas (NAIR, 1985; VERGARA, 1985; CATIE, 1986; COPIJN, 1988). Assim, sistemas agroflorestais correspondem à escala de sistema de cultivo tal como conceituado por LAURENT (1990a).

NAIR (1985) apresentou uma proposta de classif icação de sistemas agrof lorestais que tornou-se muito difundida em todo o mundo, tendo sido abordada no Brasil por DUBOIS (1989). Segundo a proposta de NAIR (1985), sistemas agroflorestais são enquadrados em quatro grandes grupos segundo a natureza dos componentes. Sistemas silvoagricolas referem-se ao cultivo de espécies arbóreas com culturas agricolas; sistemas silvopastoris referem-se ao cultivo de espécies arbóreas com pastagem e animais; sistemas agrossilvopastoris são aqueles onde espécies arbóreas são cultivadas com culturas anuais, pastagem e animais. Um quarto grupo abrange sistemas especiais, não enquadrado nos casos anteriores e que devem ser particularizados em cada situação.

Os sistemas agrof lorestais são classificados, ainda, segundo outros atributos que possuam quanto à distribuição dos componentes no tempo, quanto à distribuição dos componentes no espaço e quanto aos ob jetivos da produção (NAIR, 1985; DUBOIS, 1989).

\subsection{Principais sistemas silvoagricolas tradicionais}

As práticas modernas de agrossilvicultura têm suas origens em sistemas tradicionais de cultivos consorciados. MACDICKEN \& VERGARA (1990) associam o inicio da agrossilvicultura aos primórdios da história escrita: na Bíblia o livro de Genesis (2:8-9) descreve, segundo os autores, jardins onde crescem juntas muitas espécies de árvores que proporcionam alimento e beleza. Esta situação, segundo NAIR (1985), caracteriza um sistema agrof lorestal especial. 
Em todo o mundo, ainda hoje são inúmeros os exemplos de sistemas tradicionais de cultivo de espécies arbóreas associadas com cultivos agrícolas.

\subsubsection{Pomares mistos ou hortas caseiras}

Pomares mistos têm sido praticado pelos povos da América e da Asia, desde o início de sua história. Eles constituem, juntamente com a agricultura migratória, uma das práticas agroflorestais mais antigas (WIERSUN, 1982; VERGARA, 1985; KING, 1978; SOEMARWOTO, 1987; MACDICKEN \& VERGARA, 1990).

Pomares mistos ou hortas caseiras consistem no cultivo de diversas espécies frutiferas associadas com cultivos agricolas, com espécies arbóreas e, algumas vezes, com animais domésticos (GLIESSMAN, 1981; WIERSUN, 1982). Segundo ARNOLD (1990/91), nos pomares mistos o cultivo de espécies perenes é dominante sobre os cultivos anuais, assim como há dominância de espécies lenhosas sobre espécies herbáceas. Eles caracterizam-se pela alta complexidade, apresentando múltiplos estratos e grande variedade de espécies, com produção durante o ano todo. Seu papel fundamental é fornecer alimentos básicos para a familia; ocasionalmente, o excesso da produção é comercializado (CATIE, 1986b).

GLIESSMAN (1981) aponta as seguintes caracteristicas principais dos pomares mistos: a) são sistemas com baixa necessidade de entradas e com capacidade constante de saídas para consumo familiar; b) o sistema depende, básicamente, da mãode-obra familiar que, em função da estrutura do sistema, pode ser escalonada durante todo o ano; c) são agroecossistemas de pouco investimento econômico, apropriados para produtores de baixa renda; e d) ecológicamente, são sistemas agrícolas muito parecido com os ecossistemas naturais, devido a: alta diversidade de espécies, alta capacidade de absorção da luz solar, mecanismos de controle biológico, ciclos fechados de nutrientes, uso eficiente do espaço e alto grau de estabilidade.

\subsubsection{Agricultura migratória}

A agricultura migratória, um exemplo de sistema agroflorestal tradicional, é definida como um sistema agroflorestal sequencial caracterizado por um período curto de cultivo de terra, sucedido por um periodo maior de pousio (CATIE, 1986b). Este sistema foi uma prática comum na Europa até o final da Idade Média; 
ainda hoje, em pequena escala, há áreas na Europa sob este sistema de cultivo (SANCHEZ, 1981; LANLY, 1985; MACDICKEN, 1990; TEWARI, 1991).

Nas áreas tropicais, na década de 80 (LANLY, 1985), 500 milhões de pessoas praticavam agricultura migratória em uma superfície estimada em 410 mi lhões de hectares de florestas, o que corresponde a $8,3 \%$ das florestas tropicais do mundo. SANCHEZ (1981) quantifica o uso desta prática em área correspondente a 30\% dos solos exploráveis do mundo.

Na agricultura migratória, o processo de preparo do solo para o cultivo, por corte e queima da vegetação, altera as propriedades químicas do solo.e do ecossistema. Resumidamente: há perdas de nitrogênio, fósf oro e enxofre volatilizados na queima; redução da matéria orgânica do solo; elevação do pH e dos elementos nitrogênio, fósforo, potássio, cálcio e magnésio disponíve is no solo pela incorporação das cinzas, sendo que os três últimos podem ser perdidos em poucos meses pela lixiviação e pelo escoamento superficial. Também a temperatura e umidade do solo sofrem alterações, pela supressão da vegetação (SANCHEZ, 1981; POGGIANI et al., 1983; COUTINHO, 1990; BANDY et al, 1993; LIMA \& BATISTA, 1993). O fogo exerce, ainda, influências acentuadas sobre: a capacidade de retenção e infiltração da água no solo, a erodibilidade do solo, os microorganismos do solo, a fauna silvestre e a regeneração natural (SZOTT \& PALM, 1984; SOARES, 1985; LIMA \& BATISTA, 1993).

Na agricultura migratória, a função principal do pousio é a recuperação da capacidade produtiva do solo, pela adição de matéria orgânica e nutrientes minerais. O êxito do pousio está relacionado à capacidade da vegetação sucessional em restabelecer a ciclagem de nutrientes na parcela abandonada (CATIE, 1986).

Segundo SANCHEZ (1981), na agricultura migratória o abandono da área agrícola ocorre em razão da diminuição de produtividade, pelo esgotamento da fertilidade do solo. CATIE (1986b) indica, como fator principal do abandono da área de cultivo, a alta incidência de plantas invasoras. 


\subsubsection{Sistema taungya}

O sistema taungya caracteriza-se pelo cultivo de espécies arbóreas madeiráve is em associação com cultivos agrícolas no início do ciclo; não é considerado um sistema agroflorestal tradicional. Este sistema surgiu como uma forma de substituir a agricultura migratória que, até então, acreditava-se ser uma fonte de destruição das florestas tropicais. Foi iniciado na Birmânia, em 1856, através do incentivo do governo ao plantio da teca, Tectona grandis (WIERSUN, 1982; VERGARA, 1985; ODUOL, 1986; KING, 1978). A partir de então o sistema difundiu-se em muitos países tropicais, inclusive na América Latina (CATIE, 1986b). Trata-se de uma tecnologia agroflorestal particular cujo objetivo final é a produção de madeira, enquanto a maioria das outras tecnologias agroflorestais dirigem-se principalmente à produção agrícola (TORQUEBIAU, 1993).

O sistema taungya é o passo inicial da intensificação da agricultura migratória, pela introdução de tecnologias que possibilitem o aumento dos rendimentos econômicos dos cultivos e ou da recuperação da fertilidade do solo durante o pousio. Sua maior oportunidade dá-se em locais em que há escassez de terra para agricultura e pressão social pela sua posse (RAINTREE \& WARNER, 1986; ARNOLD , 1990/1).

O sombreamento dos cultivos, pelas árvores, determina of inal do sistema agroflorestal e o início da cultura florestal pura. A duração do período de cultivo das espécies agricolas é determinada pela densidade, velocidade de crescimento e mane jo aplicado às espécies arbóreas. O tempo de cultivo agrícola, via de regra, é de um a quatro anos (CATIE, 1986; LEIVA \& BOREL, 1993).

BUDOWSKI (1983) aponta alguns benefícios ecológicos e sócioeconômicos deste sistema: a) facilita a limpeza e manutenção do terreno, reduzindo os custos de implantação e manutenção da cultura florestal; b) propicia melhor aproveitamento da área de cultivo; c) protege e melhora o solo, especialmente se a espécie arbórea for fixadora de nitrogênio; d) favorece a ciclagem de nutrientes, em virtude das espécies florestais possuirem sistema radicular profundo; e e) utiliza a mão-de-obra de forma permanente e melhor distribuida no ano.

Do ponto de vista silvicultural, AGUIRRE-CASTILLO (1977) associa ao sistema taungya os seguintes beneficios: a) conversão da agricultura 
migratória em uma atividade mais rentável, pela fusão com a silvicultura; b) eliminação dos efeitos negativos do nomadismo, pela produção de alimentos em um ciclo curto e de madeira em um período maior; c) redução da pressão sobre os recursos florestais naturais; d) permite melhor uso do recurso solo; e e) a manutenção da espécie florestal é beneficiada pelas limpezas das culturas anuais.

Do ponto de vista econômico, CATIE (1986b) exemplifica a aplicação do sistema na Nigéria, fomentado de duas maneiras pelo serviço florestal estatal. No primeiro método, os produtores implantam a floresta juntamente com culturas anuais, beneficiando-se com a produção agrícola; a redução dos custos de implantação da floresta é de $40 \%$. No outro método há pagamento em dinheiro aos produtores, pela implantação da floresta associada com as culturas anuais; a redução nos custos de implantação é de $60 \%$.

\subsection{O sistema tradicional de cultivo da bracatinga}

A bracat inga é uma espécie florestal nativa dos climas frios do Brasil. Sua área mais expressiva e continua é na Região Sul, nos planaltos, preferencialmente acima de $700 \mathrm{~m}$ de altitude, em locais com temperaturas médias anuais de 13 a 18,50 $\mathrm{C}$ e sem déficit hidrico (ROTTA \& OLIVEIRA, 1981). Na Região Metropolitana de Curitiba - PR, a bracatinga é uma espécie cultivada tradicionalmente segundo um sistema silvoagrícola o qual foi considerado, por BAGGlo et al. (1986), como o sistema mais antigo de produção de lenha do sul do Brasil.

O sistema tradicional de cultivo de bracatinga consorciada com culturas agricolas existia já em 1909 em propriedades agricolas, nos arredores de Curitiba - PR. O cultivo da bracatinga, para produção de lenha, foi amplamente recomendado e fomentado no inicio do século (HOEHNE, 1930; NEME, 1931; DISTRIBUIČÃO..., 1942; MARTINS, 1944; VIANNA, 1954).

RAINTREE (1990) aponta três critérios para um sistema agrof lorestal satisfatório: produtividade, sustentabilidade e adotabilidade. O sistema tradicional da bracatinga satisfaz, plenamente, estes três critérios. Segundo CARPANEZZl et al. (1988) e LAURENT et al. (1990a), o sistema gera produtos lenhosos e alimenticios, mantém-se há décadas em um ambiente socio-econômico particular e sua área está em expansão. 
Por iniciativa própria dos produtores e por incentivo dos fomentos estatal e empresarial, a área de cultivo da bracatinga no Paraná, nos últimos 40 anos, teve um acréscimo de $600 \%$,correspondendo a uma taxa de crescimento médio anual de 6,4\%. Na Região Metropolitana de Curitiba o crescimento médio, nos últimos anos, foi de 5\% (LAURENT et al., 1990a).

Baseando-se na classificação proposta por NAIR (1985), o sistema tradicional de bracatinga pode ser enquadrado como: sistema silvoagrícola concomitante (quanto à distribuição dos componentes no tempo) e misturado denso (quanto à distribuição dos componentes no espaço). Quanto aos objetivos de produção, o sistema caracteriza-se como intermediário: os cultivos agricolas destinam-se, grandemente, para auto-consumo humano e animal na propriedade, enquanto a produção florestal é comercializada para capitalização (NAIR, 1985; DUBOIS, 1989; LAURENT et al., 1990a).

As considerações de diversos autores permitem enquadrar o sistema tradicional de bracatinga como uma variação do sistema taungya, com as particularidades de a cultura florestal ter ciclo curto, basear-se na regeneração natural a partir da segunda rotação e o produto florestal ser, predominantemente, lenha (BUDOWSKI, 1983; NAIR, 1985; VERGARA, 1985; CARPANEZZI et al., 1988; DUBOIS, 1989).

Na Região Metropolitana de Curitiba, LAURENT et al. (1990a) apontam a maior produtividade de lenha da bracatinga no sistema agroflorestal tradicional, comparativamente à produtividade da capoeira (floresta secundária) explorada em ciclos de 15 a 30 anos. Adicionalmente, afirmam que a Renda Liquida Efetiva e a Remuneração da Mão-de-Obra Familiar, para o sistema tradicional de cultivo da bracatinga, é duas vezes superior ao da agricultura migratória.

Segundo CARPANEZZl et al.(1988), o sistema tradicional de cultivo da bracatinga é difundido em regiões de pequena e média agricultura, pouco tecnificada, nos arredores de centros consumidores de lenha. Seu polo principal é a Região Metropolitana de Curitiba-Paraná. Nas propriedades rurais, os talhões de cultivo de bracatinga são de dois a quatro hectares e formam, na paisagem, um mosaico de diferentes idades. Eles são cortados, normalmente, entre seis e oito anos de idade. A 
lenha é comercializada, via de regra, na propriedade. O sistema pode ser esquematizado conforme a Figura 1:

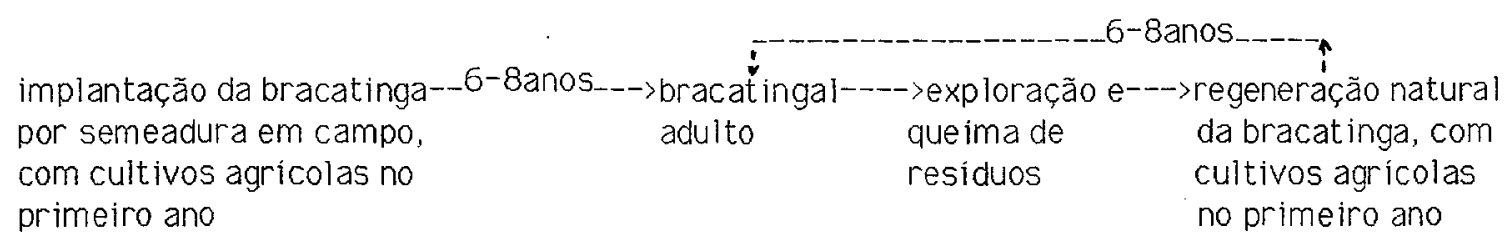

Figura 1 - Principais fases do sistema agrof lorestal tradicional do cultivo de bracatinga para produção de lenha (CARPANEZZI \& CARPANEZZI, 1992).

Uma variação importante no manejo é a ausência da cultura agricola na fase inicial, após a queima dos residuos da exploração florestal; os bracatingais resultantes são muito densos. Embora não haja dados comparativos, pressupõe-se que a ausência da fase agrícola resulta em menor produtividade da bracatinga, pelo acirramento da competição (CARPANEZZl et al. ,1988).

Estudos conduzidos por GRAÇA et al. (1986), no sistema tradicional de cultivo de bracatinga, demonstraram que a opção que traz maiores retôrnos econômicos aos produtores é a exploração da bracatinga e dos cultivos agricolas pelos proprietários. Nas propriedades em que o proprietário explorou somente a lenha, e as culturas agrícolas foram tercerizadas, o retôrno econômico foi inferior.

No sistema tradicional o homem favorece, de maneira voluntária e controlada, a regeneração natural da bracatinga, que surge intensa após a queima dos residuos de exploração. As culturas agrícolas são plantadas na primeira chuva após a queima dos residuos de exploração. Aos trinta e sessenta dias após o plantio do milho e feijão são realizadas as capinas de limpeza, nas quais são eliminadas as plântulas de bracatinga consideradas excessivas. Neste raleio inicial são deixadas em torno de dez mil plantas por hectare. Após as capinas, outras sementes germinam, em consequência do efeito da insolação sobre as sementes contidas no banco de sementes; assim, a lotação inicial do bracatingal aumenta (BAGGIO et al., 1986; CARPANEZZl et al. 1988).

Em rotações baseadas na regeneração natural, a densidade de plantas de bracatinga é elevada e variável após a coitheita do mi iho, situando-se entre 
dez mil e quarenta mil plantas por hectare. Após o cultivo agricola inicial os agricultores, como regra, não fazem capinas ou raleios. Assim, estabelece-se forte competição e ocorre mortalidade acentuada até a idade de quatro a cinco anos, quando a densidade torna-se mais estável. O número de plantas por hectare, na idade de exploração mais frequente (seis a oito anos), é relativamente constante, quer se refira somente à bracatinga ou a todas as espécies arbóreas. Nesta idade, a lotação de bracatinga é de 2200 -+ 800 plantas por hectare, para DAP a partir de $5 \mathrm{~cm}$ (CARPANEZZI \& ARHENS, 1984; BAGG10 et al., 1986; CARPANEZZI et al., 1988).

Comparando-se as poucas descrições originais do sistema tradicional, em épocas diferentes, observa-se que a fase de implantação sofreu avanços, mas que continuam inexist indo quaisquer tratos silviculturais no período pós-cultivos agrícolas (HOEHNE, 1930; MARTINS, 1944; NOWACKI, 1954; DELEAGE et al., 1984; GRAÇA et a1., 1986; BAGG10 et al., 1986; CARPANEZZl et al., 1988; CARPANEZZl, 1989). As mudanças das práticas de cultivo foram, fundamentalmente: a popularização da implantação da bracatinga por semeadura em covas, o controle de formigas cortadeiras, o uso de cultivar moderna de mitho e, por alguns produtores, a adubação das culturas agricolas (CARPANEZZI \& CARPANEZZI, 1992).

\subsection{Caracteristicas botânicas, ecológicas e silviculturais da bracat inga}

\subsubsection{Caracteristicas botânicas}

A bracatinga, Mimosa scabrellaBenth., Leguminosae Mimosoideae, é uma árvore perenifólia que, comumente, atinge 15 a $20 \mathrm{~m}$ de al tura e $40 \mathrm{~cm}$ de DAP, apresentando tronco reto e esbel to quando em maciços, ou curto e ramificado em árvores isoladas. São reconhecidas e cultivadas duas variedades botânicas de Mimosa scabrella: a variedade tipica (bracatinga, bracatinga-comum) e a variedade aspericarpa (Hoehne) Burkart (bracatinga, bracatinga-argentina). Ambas têm ocorrência natural restrita ao Brasil. A variedade aspericaroa tem fenologia reprodutiva própria e frutos maiores e mais rugosos; ela tem, também, folhagem mais clara, donde supõe-se vir o nome vulgar "bracatinga-argentina"(INOUE et al., 1984; CARPANEZZI et al., 1988; CARPANEZZI \& CARPANEZZI, 1992). 
As árvores de bracatinga-comum podem iniciar o florescimento a partir de oito meses de idade. Os botões florais começam a abrir a partir de abril e a floração prolonga-se até setembro. Ocorrem variações anuais em consequência de alterações climáticas. O pico da floração ocorre no inverno, o que a torna importante para a produção de mel. A frutificação é de dezembro a março, sendo os meses de dezembro a fevereiro o período mais indicado para coleta de sementes. A variedade aspericaroa floresce, no Paraná, de novembro a dezembro e suas sementes são coletadas de março a maio (CATHARINO et al., 1982; CARPANEZZI et al., 1988).

Estudos de biologia floral da bracatinga-comum, realizados por CATHARINO et al. (1982), indicam tratar-se de uma espécie alógama, com predominância de flores hermafroditas sobre as flores masculinas, com ligeira protoginia. A espécie é de polinização cruzada e alofílica, isto é, as flores não apresentam características morfológicas que exijam especialização do pol inizador. Os agentes polinizadores mais prováveis são insetos e, entre eles, as abelhas Apis melliferae Trigonasp.

\subsubsection{Características ecológicas}

Segundo HOLDRIDGE (1978) a sucessão caracteriza-se por uma série de fases do crescimento da vegetação, cuja estrutura e composição tornam-se, com o tempo, mais complexas. À medida que a comunidade vegetal desenvolve-se ocorrem, também, mudanças na comunidade animal que habita a área. O solo se desenvolve e este fenômeno constitui uma das mudanças ambientais mais notáveis durante a sucessão. Assim, a sucessão envolve um amplo desenvolvimento do ecossistema em uma determinada área. Há vários tipos de sucessão, que dependem de: se o desenvolvimento cobre a série completa desde a litosfera desvegetada ou a água (sucessão primária), ou se começa repovoando várias secções reduzidas de uma comunidade já existente (sucessão secundária).

Em resumo, a sucessão secundária é um processo ecológico caracterizado por mudanças no ecossistema, após uma perturbacão natural ou humana, que conduzem a comunidade, progressivamente, a uma estrutura e composição mais complexas (GOMEZ-POMPA \& WIECHERS, 1976). 
BUDOWSKI (1965) apresenta a seguinte classificação para as espécies arbóreas segundo a sucessão secundária em florestas tropicais: espécies pioneiras, espécies secundárias e espécies clímax.

VAZQUEZ-YANES (1980) descreve, como uma das caracteristicas mais interessantes e atraentes do desenvolvimento sucessional da vegetação, a intervenção no processo sucessional de um conjunto de árvores pioneiras. Estas árvores não fazem parte da vegetação madura, apresentam crescimento extraordinariamente rápido, alcançam a maturidade em poucos anos, produzem numerosos propágulos latentes e têm vida muito curta em comparação com outras espécies arbóreas de etapas serais posteriores. Estas árvores, ao estabelecer-se, geram condições ambientais peculiares que permitem o crescimento de outras plantas, características de etapas sucessionais mais tardias.

Na Tabela 1 estão reunidas as principais características das espécies de diferentes estágios da sucessão. 
Tabela 1. - Caracteristicas das espécies pioneiras, secundárias e climax

\begin{tabular}{lllll}
\hline Características & Pioneiras & Secundárias & Clímax & Autor \\
\hline Ciclo de vida (anos) & $<30$ a 50 & $>100$ & $>100$ & 1 \\
Número de estratos da & $1-2$ & & $4-5$ & 2 \\
vegetação & intolerantes & tolerantes & tolerantes & 2 \\
Tolerância à sombra & clareiras grandes & clareiras pequenas & não clareiras & 3 \\
Dependência de clareiras & longa & média/curta & curta & 2 \\
Viabilidade das sementes & animais/vento & vento & animais grandes & 2 \\
Dispersão das sementes & contínua & anual & anual & 4 \\
Produção de sementes & frequente & ausente & recalcitrante & 4 \\
Dormência das sementes & presente & ausente & ausente & 4 \\
Banco de sementes & lutadora & ambos & formadora & 5 \\
Estratégia de plântulas & muito rápido & rápido & lento & 2 \\
Crescimento & clara/leve & intermediária & escura/densa & 4 \\
Madeira & superficiais & intermediária & profundas & 4 \\
Raízes & alta & intermediária baixa & 4 \\
Produção de folhas & & & \\
\hline
\end{tabular}

Fonte: (1) MARTINEZ-RAMOS (1985); (2) BUDOWSKI (1965); (3)DENSLOW (1980); (4) WHITMORE (1983); (5) OLDEMAN (1978).

A bracatinga é uma espécie essencialmente heliófila, muito exigente quanto à intensidade de luz em todas as fases do seu desenvolvimento. Ela comporta-se como espécie pioneira na vegetação secundária do planalto do sul do Brasil, podendo manter-se até a formação de capoeirões. Na vegetação secundária de clareiras naturais ou antrópicas das matas primárias, ela apresenta destacada agressividade, substituindo gradativamente as espécies herbáceas e arbustivas dos estágios iniciais da sucessão (KLEIN, 1981).

A Tabela 2 ilustra o comportamento demográfico da bracatinga ao longo da sucessão. 
Tabela. 2 - Características de talhões de regeneração natural de bracatinga de diferentes idades, no Estado do Paraná. Arvores com DAP maior ou igual a $5 \mathrm{~cm}$.

\begin{tabular}{|c|c|c|c|c|}
\hline \multirow{2}{*}{$\begin{array}{l}\text { Idade } \\
\text { (anos) }\end{array}$} & \multicolumn{2}{|c|}{ Bracatinga } & \multicolumn{2}{|c|}{ Outras espécies } \\
\hline & Plantas/ha & Altura(m) & Plantas/ha & Altura(m) \\
\hline 5 & 2314 & 10,34 & 102 & 6,12 \\
\hline 7 & 2170 & 8,75 & 220 & 6,40 \\
\hline 9,5 & 1691 & 15,20 & 191 & 6,27 \\
\hline 12 & 815 & 13,60 & 1673 & 8,05 \\
\hline 18 & 509 & 17,77 & 2064 & 7,72 \\
\hline
\end{tabular}

Fonte: KAGEYAMA et al. (1989)

A bracatinga é uma espécie de rápido crescimento e de grande aptidão para colonização de áreas abertas e bem iluminadas, como terrenos queimados e beira de estradas. Suas sementes apresentam dormência tegumentar e formam banco no solo; a dormência é interrompida pela temperatura, permitindo a germinação. Maciços com frequência elevada de bracatinga ocorrem como consequência da ação do homem, através da el iminação da floresta primária para agricultura ou da ação do fogo (REITZ et al., 1978; INOUE et al., 1984; CARPANEZZI et al., 1988).

BARROS (1961) já considerava a bracatinga uma espécie valiosa para a recuperação de áreas degradadas. Ela apresenta crescimento satisfatório e reprodução precoce e prolífica. Propicia, também, deposição anual elevada de serrapitheira rica, principalmente, em nitrogênio e fósforo; a deposição tende a decrescer com a idade (CHIARANDA et al., 1983; CARPANEZZI et al., 1984; POGGIANI \& MONTEIRO, 1990). Estima-se, como valores médios anuais durante o periodo de rotação no sistema tradicional, deposições de 6 a 7 toneldadas de material orgânico contendo $150 \mathrm{~kg}$ de nitrogênio, trazendo ganhos comprovados ao solo (CARPANEZZI et al., 1988; POGGIANI \& MONTEIRO, 1990).

Deposições elevadas de material orgânico e nutrientes, superiores aos valores previstos por BRAY \& GORHAM (1964), parecem estar associadas à capacidade de fixação simbiótica de nitrogênio (ZAVITKOVSKI \& NEWTON, 1971) e constituem um mecanismo facilitador da sucessão (LUKEN, 1991). 


\subsubsection{Caracteristicas silviculturais}

A bracatinga apresenta características consideradas por COPIJN (1987) como importantes na seleção de espécies florestais para cultivo em sistemas consorciados: crescimento rápido, capacidade de fixar nitrogênio, fornecer vários tipos de produtos e usos e possuir foinas pequenas ou foliolos.

A made ira de bracatinga proporciona lenha muito boa e carvão de excelente qualidade. No Brasil, a espécie foi cultivada inicialmente para fornecer combustivel para locomotivas a vapor. Atualmente, a madeira é utilizada como combustivel lenhoso de diversos usos e para produção de carvão (HOEHNE, 1930; MARTINS, 1944; LAURENT et. al., 1990a). CARPANEZZl et al. (1988) apontam usos atuais secundários para madeira de bracatinga: madeira roliça usada como escoras na construção civil; madeira serrada para vigamento, ripas de telhado e na indústria moveleira em partes internas de móveis etc.

A madeira de bracatinga tem densidade relativamente elevada quando comparada à de Eucalyptus grandis $10,580 \mathrm{~g} / \mathrm{m}^{3}$ e $0,478 \mathrm{~g} / \mathrm{m} 3$, respectivamente). Ela apresenta, também, valores superiores para teor de lignina, rendimento em carvão e teor de carbono fixo. O teor de cinza do carvão de bracatinga é superior ao de $E$. grandis, $1,9 \%$ e $0,7 \%$, respectivamente, constituindo uma desvantagem da bracatinga em relação ao eucal ipto(CARPANEZZI et al., 1988).

Graças ao seu potencial produtivo, a bracatinga tem sido introduzida em outros Estados brasileiros e em alguns países. VECCHI (1930) registrou a introdução da bracatinga em 1927, para produção de lenha, no Estado de São Paulo, com sementes originárias do Paraná. A partir dos povoamentos introduzidos houve fomento de mudas e sementes no Estado, pelo Serviço Florestal.

A primeira introdução da bracatinga na América Central parece remontar ao início da década de 40, na Guatemala, onde rapidamente adquiriu fama como árvore sombreadora em cafezais (STANDLEY \& STEYERMARK, 1946). Mais recentemente, a espécie foi revalorizada na região, como na Costa Rica e Honduras, para sombreamento de café e produção de energia (PICADO, 1985; CATIE, 1991). Na Africa ela é considerada uma espécie mui to promissora para zonas de aititude elevada (ICRAF, 1992). 
No Brasil, constata-se que introduções da bracatinga em locais demasiadamente quentes ou secos causam, de modo proporcional, redução da duração de vida. Todavia, devido ao crescimento inicial rápido e a beneficios paralelos que proporciona, como sombreamento e fixação de nitrogênio, a espécie é valiosa mesmo em rotações curtas, principalmente em sistemas agrof lorestais em terrenos ricos e adubados (CARPANEZZI \& CARPANEZZI, 1992). Para energia, a qualidade da madeira de rotações curtas é razoável: BAGGlo et al. (1992) obtiveram, aos 3 anos de idade, madeira com densidade básica de $0,44 \mathrm{~g} / \mathrm{m}^{3}$ e poder calorífico de $4555 \mathrm{Kcal} / \mathrm{Kg}$.

Segundo CARPANEZZI et al. (1988), a produtividade em bracatingais do sistema tradicional de cultivo, na Região Metropolitana de Curitiba, varia de 7 a $15 \mathrm{~m}^{3} / \mathrm{ha}$ ano, com valor médio de $12,5 \mathrm{~m}^{3}$, equivalente a $22 \mathrm{st}$. CARPANEZZI \& CARPANEZZI (1992) relacionam este patamar de produtividade com as características desfavoráveis do ambiente físico e das práticas culturais presentes no sistema tradicional.

Produtividades muito superiores às do sistema tradicional de cultiva têm sido constatadas, associadas a condições ambientais mais favoráveis. Em plantações agricolas tecnificadas, com bracatinga em linhas intercaladas, BAGGIO et al.(1992) obtiveram produtividade de 37 st/ha. ano, aos 3 anos de idade, em povoamentos com 1500 árvores por hectare. Na Costa Rica, PICADO (1985) determinou produtividade de 57 st/ha. ano para bracatinga associada com café, em populações de 250 árvores por hectare. Em bracatingais manejados para sombra de cafezais na América Central, a maior produtividade média anual citada por CATIE (1991) foi de $20 \mathrm{~m}^{3} / \mathrm{ha}$, aos 4 anos. CARPANEZZl et al. (1988) mencionaram produtividades anuais de 30 a $36 \mathrm{~m}^{3} /$ ha em talhão não consorciado de 4 anos em Concórdia-SC, um sitio favorecido pelas condições edafoclimáticas. Em um ensaio realizado na Provincia de Misiones, Argentina, VOLKART et al. (1991) relatam, para plantios com 2500 plantas por hectare, a produtividade de $86 \mathrm{~m}^{3} /$ ha. ano, aos 4 anos de idade.

\section{5 - Culturas agrícolas associadas `a bracatinga}

Milho e feijão associados são as espécies agrícolas mais plantadas no sistema tradicional de cultivo da bracatinga; abóbora e mandioca são menos 
importantes. O milho é plantado em covas espaçadas comumente de $120 \times 60 \mathrm{~cm}, 100$ $\times 80 \mathrm{~cm}$ ou $100 \times 100 \mathrm{~cm}$, colocando-se três a cinco sementes por cova (BAGGIO et al., 1986; CARPANEZZl et al., 1988). Esta é uma disposição antiga, ainda preservada, e contrasta com as recomendações técnicas atuais ( para mi lho solteiro) de plantio em linhas com espaçamentos de 80 a $100 \mathrm{~cm}$ entre linhas e sete a nove sementes por metro linear (IAPAR, 1982). O feijão é plantado em linhas intercalares 'as do milho, colocando-se três a cinco sementes por cova; as covas distam entre si, comumente 40 a $60 \mathrm{~cm}$ ( BAGGIO et al. , 1986; CARPANEZZl et al., 1988).

Na Região Metropolitana de Curitiba, atualmente, a cultivar de mi lho mais empregada no sistema agroflorestal tradicional é a $A G$ 301, de porte baixo. Esta cultivar é adequada para sistemas com nível tecnológico elevado e, por isto, tem menor produtividade, no sistema tradicional de cultivo de bracatinga, do que o milho branco tradicional da região, de porte grande (CARPANEZZI, 1989).

Em experimentos conduzidos em 1988 em Bocaiúva do Sul - PR, variedades de milho e feijão foram comparadas, dentro do sistema tradicional de cultivo da bracatinga. As variedades de mi lho que apresentaram maior produtividade foram Azteca, Cargil 511-A e OCEPAR 202 e, para o feijão, a variedade Tibagi (LAURENT et al., 1990b).

No sistema agrof lorestal tradicional, o preparo da área consiste unicamente em queimar os restos da vegetação anterior para limpar o terreno e, quando houver banco de sementes de bracatinga no solo, promover sua germinação. Á queimada marca o inicio do ano agrícola e é realizada comumente após 15 de setembro, para evitar danos por geadas. Mi iho e feijão são plantados nas primeiras chuvas após a queimada. Poucos agricultores adubam as culturas agrícolas e o fazem com doses baixas, sem prévia correção de acidez. São realizados o controle de formigas cortadeiras e tratos culturais para as culturas agrícolas, em geral duas capinas, aos trinta e sessenta dias depois da semeadura. O fei jão é colhido em janeiro e o milho em maio ou junho, quando as plantas de bracatinga têm cerca de nove meses (DELEAGE et al., 1984; CARPANEZZI et al., 1988; CARPANEZZI \& CARPANEZZI, 1992). 


\section{MATERIAIS E MÉTODOS}

\subsection{Caracterização da área experimental}

O experimento foi realizado no municipio de Bocaiúva do Sul - PR, no norte da Região Metropol itana de Curitiba, em uma propriedade distante $1,5 \mathrm{~km}$ da cidade em direção `a localidade denominada Cedrinho (Figura 2). A cidade de Bocaiúva do Sul tem cota altitudinal de $980 \mathrm{~m}$ e coordenadas $25013^{\prime} \mathrm{S}$ e $49006 \mathrm{~W}$ (PARANA ..., 1977).

Segundo a classificação de Koeppen, o clima de Bocaiúva do Sul é do tipo Cfb, subtropical úmido mesotérmico, com ocorrência de geadas severas e frequentes no inverno, sem estação seca definida. A temperatura média do mês mais quente é de $21^{\circ} \mathrm{C}$ e a do mês mais frio não ultrapassa $13^{\circ} \mathrm{C}$. A temperatura média anual situa-se entre 16 e 170 C, a precipitação média anual entre 1400 e $1500 \mathrm{~mm}$ e a média anual de umidade relativa do ar entre 80 e $85 \%$ (IAPAR, 1978).

O experimento foi implantado em uma propriedade de 49,6 ha, típica do sistema agrário regional. A atividade principal desenvolvida na propriedade é o cultivo da bracatinga, consorciada com milho e feijão no inicio de cada rotação. 


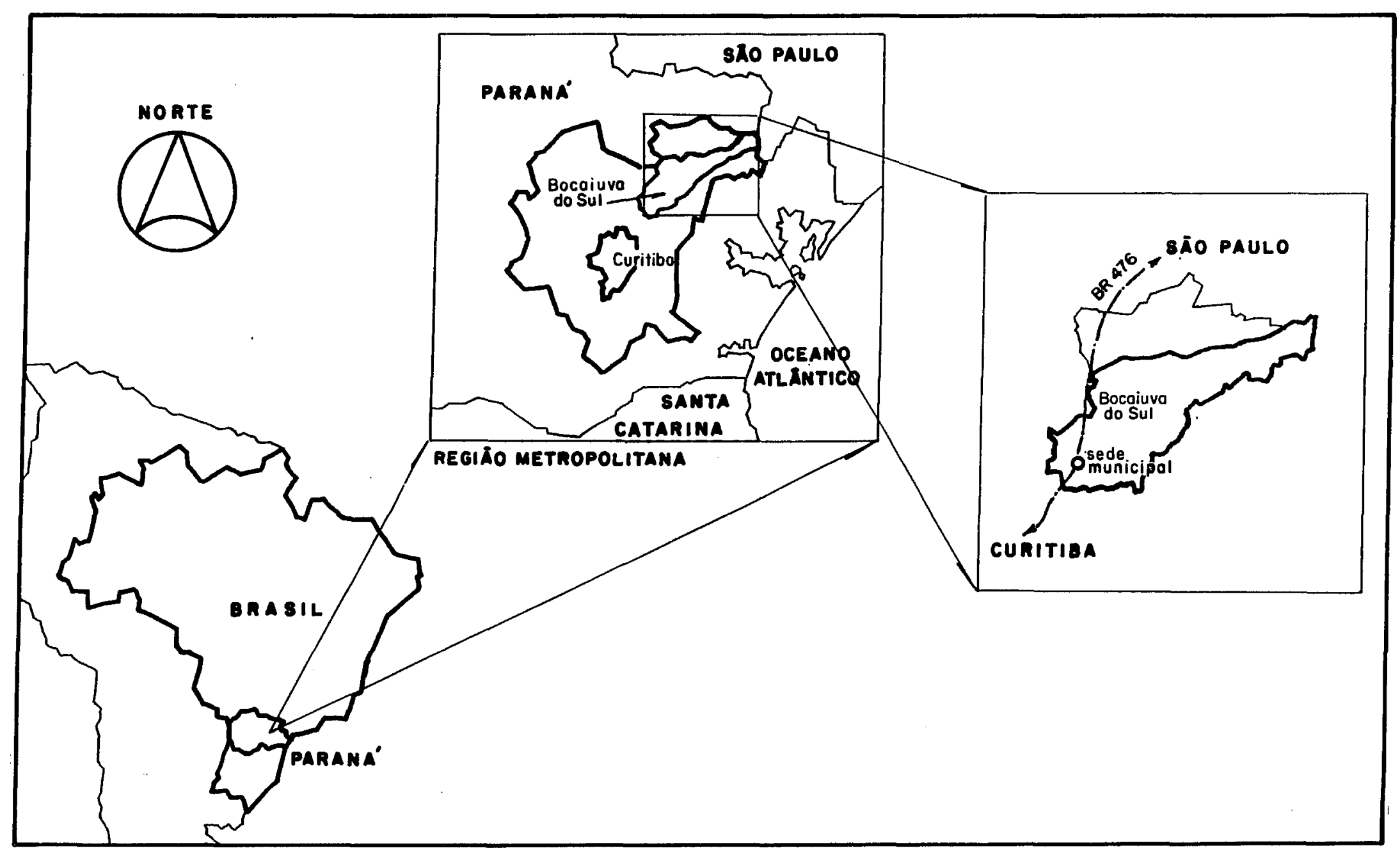

Figura 2. Localização geográfica da área experimental 
As Tabela 3 e Figura 3 apresentam dados mensais sobre a pluviosidade, coletados pela EMBRAPA-CNPF em Colombo-PR, a cerca de $30 \mathrm{~km}$ do experimento.

Tabela 3 - Precipitação e dias com chuvas no ano agrícola de implantação do experimento (1990/91)

\begin{tabular}{lcc}
\hline Meses & Precipitação $(\mathrm{mm})$ & № de dias com chuva \\
\hline outubro 1990 & 153,2 & 13 \\
novembro & 182,0 & 9 \\
dezembro & 65,1 & 6 \\
janeiro 1991 & 107,9 & 13 \\
fevereiro & 107,3 & 8 \\
março & 159,2 & 18 \\
abri1 & 44,6 & 9 \\
maio & 41,5 & 7 \\
junho & 135,8 & 11 \\
\hline
\end{tabular}

Fonte: Posto meteorológico da EMBRAPA-CNPF

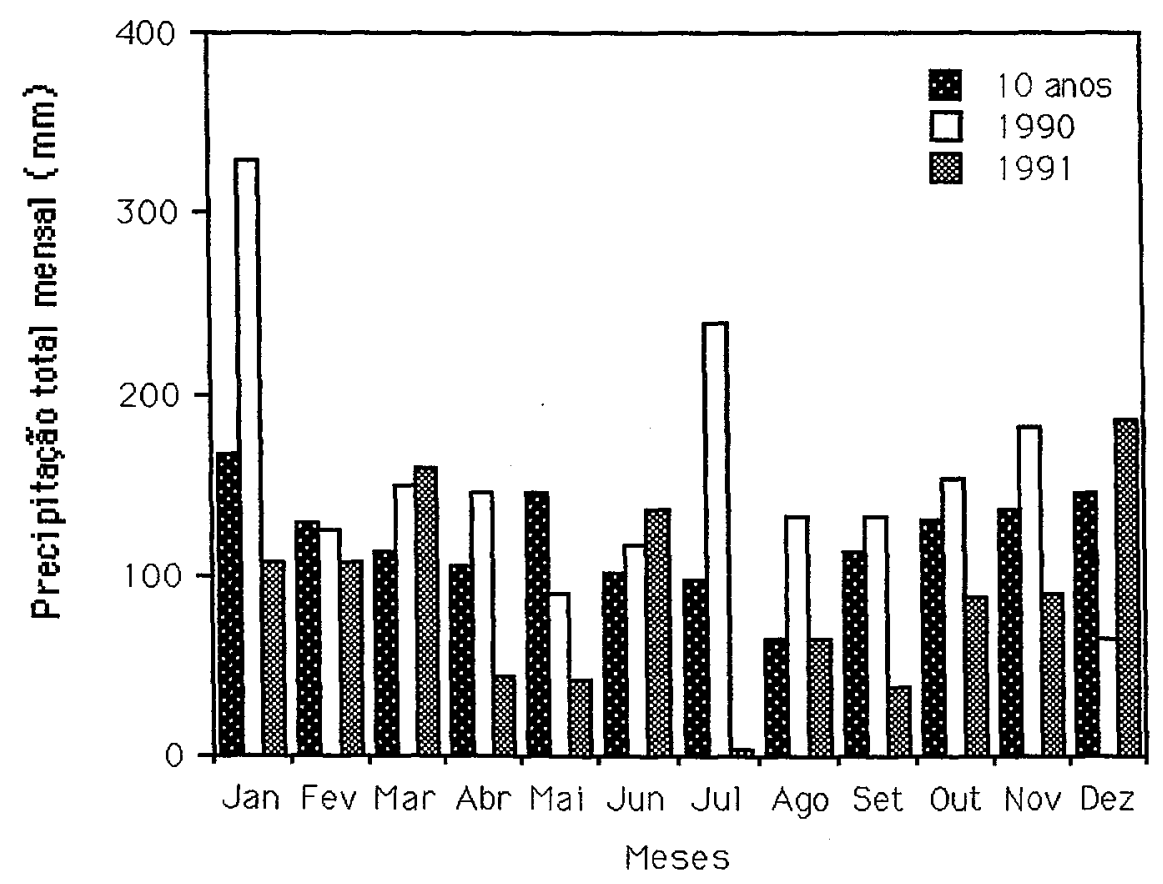

Figura 3. Precipitação mensal média de 10 anos e no período de experimentação. Dados coletados no posto meteorológico do CNPF-EMBRAPA 
A vegetação original do local do experimento é classificada, segundo MAACK (1968), como Mata de Araucária e, segundo VELOSO et al. (1991), como Floresta Ombrófila Mista Montana. Este tipo de vegetação ocupava quase que inteiramente o planalto acima de $500 \mathrm{~m}$ de altitude nos Estados do Paraná, Santa Catarina e Rio Grande do Sul. Sua principal característica é a alta frequência de Araucaria angustifolia, que tem posição emergente no perfil da mata

O relevo da área experimental é ondulado fase floresta subtropical perenifolia. A vegetação original do local do experimento foi explorada seletivamente e substituida por bracatinga. O bracatingal inicial foi implantado por semeadura direta na cova, em espaçamento aproximado de $1,00 \mathrm{~m} \times 0,60 \mathrm{~m}$, consorciado com mi tho e feijão. No talhão do experimento, com 3,2 ha, o cultivo da bracatinga estava no início da terceira rotação, portanto com cerca de 14 anos de produção, considerando-se um cicio de corte de 7 anos.

Em cada bloco foram retiradas, aleatoriamente, em toda a extensão do bloco, cinco amostras simples de solo em cada profundidade, para formação de uma amostra composta. As Tabelas 4 e 5 apresentam os resultados das análises física e química das amostras de solo na área do experimento, coletadas após a queima dos resíduos da exploração da bracatinga e antes do plantio das culturas agrícolas. 
Tabela 4 - Dados de granulometria do solo do experimento. Amostras coletadas em outubro de 1990, após queima dos residuos florestais.

\begin{tabular}{|c|c|c|c|}
\hline \multirow{2}{*}{$\begin{array}{l}\text { Profundidade } \\
(\mathrm{cm})\end{array}$} & \multicolumn{3}{|c|}{ Granulometria $(\%)$} \\
\hline & Areia & Silte & Argila \\
\hline \multicolumn{4}{|l|}{ Bloco 1} \\
\hline $\begin{array}{c}0-5 \\
5-10 \\
10-20 \\
20-30\end{array}$ & $\begin{array}{l}17,0 \\
19,0 \\
20,0 \\
19,0\end{array}$ & $\begin{array}{l}31,0 \\
31,0 \\
28,0 \\
26,0\end{array}$ & $\begin{array}{l}52,0 \\
50,0 \\
52,0 \\
55,0\end{array}$ \\
\hline \multicolumn{4}{|l|}{ Bloco 2} \\
\hline $\begin{array}{c}0-5 \\
5-10 \\
10-20 \\
20-30\end{array}$ & $\begin{array}{l}32,0 \\
36,0 \\
37,0 \\
37,0\end{array}$ & $\begin{array}{l}34,0 \\
31,0 \\
30,0 \\
27,0\end{array}$ & $\begin{array}{l}34,0 \\
34,0 \\
33,0 \\
36,0\end{array}$ \\
\hline \multicolumn{4}{|l|}{ Bloco 3} \\
\hline $\begin{array}{c}0-5 \\
5-10 \\
10-20 \\
20-30\end{array}$ & $\begin{array}{l}24,0 \\
26,0 \\
29,0 \\
31,0\end{array}$ & $\begin{array}{l}24,0 \\
28,0 \\
23,0 \\
25,0\end{array}$ & $\begin{array}{l}52,0 \\
46,0 \\
48,0 \\
44,0\end{array}$ \\
\hline \multicolumn{4}{|l|}{ Bloco 4} \\
\hline $\begin{array}{c}0-5 \\
5-10 \\
10-20 \\
20-30\end{array}$ & $\begin{array}{l}34,0 \\
33,0 \\
34,0 \\
34,0\end{array}$ & $\begin{array}{l}28,0 \\
27,0 \\
26,0 \\
26,0\end{array}$ & $\begin{array}{l}38,0 \\
40,0 \\
40,0 \\
40,0\end{array}$ \\
\hline
\end{tabular}


Tabela 5 - Dados de análise química do solo do experimento. Amostras coletadas em outubro de 1990, após queima dos residuos florestais

\begin{tabular}{|c|c|c|c|c|c|c|}
\hline \multirow[t]{2}{*}{$\begin{array}{l}\text { Profundidade } \\
\quad(\mathrm{cm})\end{array}$} & \multirow[t]{2}{*}{$\begin{array}{l}\mathrm{pH} \mathrm{em} \\
\mathrm{CaCl}_{2}\end{array}$} & $\mathrm{Al}^{+3}$ & $\mathrm{Ca}+\mathrm{Mg}$ & \multirow[t]{2}{*}{$\begin{array}{l}\text { Matéria } \\
\text { Orgânica }\end{array}$} & \multirow[t]{2}{*}{$\begin{array}{l}P \\
\text { ppm }\end{array}$} & \multirow[t]{2}{*}{$\begin{array}{l}\mathrm{K} \\
\mathrm{ppm}\end{array}$} \\
\hline & & meq./ & $100 \mathrm{~cm}^{3}$ & & & \\
\hline
\end{tabular}

Bloco 1

$\begin{array}{crrrrrr}0-5 & 4,13 & 1,0 & 4,5 & 14,19 & 10 & 155 \\ 5-10 & 3,88 & 2,2 & 2,1 & 7,55 & 2 & 115 \\ 10-20 & 3,76 & 2,7 & 1,3 & 5,79 & 1 & 63 \\ 20-30 & 3,91 & 2,5 & 0,8 & 4,34 & 1 & 63\end{array}$

Bloco 2

$\begin{array}{ccccccc}0-5 & 4,07 & 1,0 & 4,6 & 9,82 & 7 & 82 \\ 5-10 & 3,78 & 2,8 & 2,5 & 7,11 & 3 & 67 \\ 10-20 & 3,66 & 3,7 & 1,5 & 4,59 & 2 & 40 \\ 20-30 & 3,76 & 3,9 & 0,9 & 2,36 & \text { traço } & 26\end{array}$

Bloco 3

$\begin{array}{rrrrrrr}0-5 & 4,68 & 0,6 & 7,0 & 8,71 & 3 & 100 \\ 5-10 & 3,92 & 2,6 & 2,0 & 12,13 & 2 & 120 \\ 10-20 & 4,06 & 2,2 & 3,0 & 4,84 & 1 & 81 \\ 20-30 & 3,94 & 3,1 & 0,7 & 2,15 & 1 & 39\end{array}$

Bloco 4

\begin{tabular}{ccccccc}
$0-5$ & 4,04 & 1,6 & 3,6 & 10,0 & 7 & 100 \\
$5-10$ & 3,77 & 3,0 & 1,5 & 6,29 & 1 & 86 \\
$10-20$ & 3,76 & 3,6 & 1,5 & 6,10 & 1 & 69 \\
$20-30$ & 3,78 & 3,5 & 0,9 & 3,65 & 1 & 41 \\
\hline
\end{tabular}

Para caracterização do solo foram retiradas amostras dos perfis em nove pontos da encosta, com trado, aos 41 meses da implantação do experimento. Foram identificados dois tipos de solo na área experimental. Como solo predominante encontrou-se Cambissolo profundo distrófico epieutrófico; secundáriamente constatouse Latossolo Vermelho-Amarelo pouco profundo álico, textura argilosa, este abrangendo uma pequena área restrita aos blocos 1 e 3. O Latossolo possui horizonte A moderado. Nos horizontes superficiais do Cambissolo constatou-se valores texturais que o definem como textura média ( $34 \%$ de argila); em profundidade $(80-110 \mathrm{~cm}$ ) verificou-se um incremento no teor de argila, todavia não suficientemente elevado a ponto de enquadrar o horizonte $B$ como textural. 


\subsection{Delineamento experimental}

O experimento foi implantado em blocos ao acaso com quatro repetições, em um bracatingal de regeneração natural recentemente induzida por queima. Na área que circunda o experimento foram cultivados milho e feijão consorciados com bracatinga, no sistema tradicional. Foram idealizados os seguintes tratamentos:

T1 - Sistema agroflorestal tradicional (SAT): densidade da bracatinga reduzida para $8,5 \mathrm{mil}$ plantas/ha, milho a $120 \times 60 \mathrm{~cm}$ e uma linha de feijão; sem adubação das culturas agricolas; duas capinas;

T2 - Sistema agrof lorestal melhorado (SAM): densidade da bracatinga reduzida para $8,5 \mathrm{mil}$ plantas/ha, milho a $160 \times 25 \mathrm{~cm}$ e duas linhas de fei jão; adubação nas culturas agricolas com fósforo na cova e nitrogênio em cobertura; duas capinas;

T3 - Culturas agrícolas (CA): milho a $80 \times 25 \mathrm{~cm}$ e duas linhas de feijão; adubação nas cuituras agricolas com fósforo na cova e nitrogênio em cobertura; duas capinas;

T4 - Sistema florestal tradicional (SFT): população total de plantas de bracatinga, sem adubação e sem capinas;

T5 - Sistema florestal melhorado 1 (SFM1): densidade da bracatinga reduzida para 9,5 mil plantas/ha; sem adubação; duas capinas; e

T6 - Sistema florestal melhorado 2 (SFM2): densidade da bracatinga reduzida para 3,3 mil plantas/ha; sem adubação; duas capinas.

O tamanho total da parcela foi de $89,6 \mathrm{~m}^{2} \cdot(11,2 \times 8 \mathrm{~m})$. Foi deixada uma bordadura de $2 \mathrm{~m}$ no sentido da maior extensão e $1,5 \mathrm{~m}$ no sentido de menor extensão da parcela restando, assim, uma área útil de $36 \mathrm{~m}^{2}$ por parcela $(7,2 \times 5 \mathrm{~m})$.

\section{3. Implantação e condução do experimento}

Para clareza emprega-se, neste trabalho, o termo "raleio" para eliminação de plantas de bracatinga durante as capinas e o termo "desbaste" para eliminação de plantas após as capinas. 


\subsubsection{Implantação e condução da bracatinga}

Para a implantação do experimento, o preparo da área foi por queima dos resíduos da exploração da bracatinga. A que ima foi realizada na segunda quinzena de setembro de 1990. O fogo, além de limpar o terreno, induziu a quebra de dormência das sementes de bracatinga presentes no solo.

Em 01.10.90 foi feita a demarcação do experimento, com locação dos blocos e sorteio dos tratamentos nos blocos. O plantio do milho e feijão no experimento foi realizado nos dias 9 e 10.10.90, simultaneamente ao plantio das culturas agrícolas ao redor da área experimental, executado pelo agricultor segundo 0 sistema tradicional.

Na primeira capina das culturas agrícolas, em 10.11.90, aos 30 dias após o plantio do milho e feijão, efetuou-se raleio da bracatinga em todos os tratamentos, independente das densidades previstas, com exceção do tratamento SFT. Neste raleio foram seguidos critérios estabelecidos pelos agricultores os quais conservam, normalmente, uma planta de bracatinga por metro quadrado.

Novas sementes germinaram após a primeira capina. Nos tratamentos SAT, SAM, SFM1 e SFM2, em 10.12.90 foram identificadas e contadas todas as plantas de bracatinga que nasceram antes e após a primeira capina. Considerou-se plantas germinadas após a primeira capina todas as que apresentavam altura inferior a $30 \mathrm{~cm}$. Imediatamente a seguir foi feita a segunda capina de limpeza, em todos os tratamentos, exceto no tratamento SFT. Nesta capina não foi eliminada nenhuma plântula de bracatinga.

Em 28.01.91, aproximadamente 4 meses após a queima, foi realizado desbaste da bracatinga para a densidade prevista nos tratamentos. 0 desbaste foi efetuado por arrancamento manual e seguiu os critérios de vigor e distribuição espacial.

Aos 4 meses de idade, antes e após o desbaste, foram medidos a altura e o diâmetro a $10 \mathrm{~cm}$ do solo; aos $11,15,20$ e aos 29 meses de idade mediu-se a altura total e o DAP. Os dados da medição feita aos 11 meses de idade foram descartados, por ocorrência de erros nos trabalhos de campo. 


\subsubsection{Implantação e condução das culturas agricolas}

No preparo do solo para cultivo foi adotado o método convencional usado pelos agricultores,ou seja, queima dos residuos da exploração do bracatingal.

As cultivares plantadas de milho e fei jão foram, respectivamente, OCEPAR 202 e Tibagi. O plantio foi feito nos dias 09 e 10 de outubro de 1990, com semeadora manual, dotada de dispositivo mecânico para adubação em cova em quantidades controladas.

Nos tratamentos SAM e CA foi feita adubação com superfosfato simples na cova, durante o plantio, na proporção de 2,5 grama por cova para o milho e 1,5 grama por cova para o feijão. Nestes tratamentos, aos 68 dias do plantio foi feita adubação de cobertura no milho na proporção de $100 \mathrm{~kg} /$ ha de uréia. A lotação de plantas de milho no tratamento CA (42 000 covas/ha) era o dobro do tratamento SAM (21 000 covas/ha); assim, a quantidade de uréia aplicada por cova, no tratamento SAM, foi o dobro da aplicada no tratamento CA.

Os tratos culturais realizados foram: capinas de limpeza aos 30 e 60 dias após o plantio e desbaste na cova do milho. No desbaste foram deixadas 1 ou 2 plantas por cova nos tratamentos SAM e CA (tratamentos melhorados) e 1, 2,3 ou 4 plantas por cova no tratamento SAT (tratamento agroflorestal tradicional), neste caso simulando a prática adotada pelos agricultores. O milho e o feijão foram cultivados somente no primeiro ano.

O feijão foi colhido aos 96 dias de plantio e o milho aos 210 dias do plantio. A colheita foi feita na área total da parcela e a avaliação da produção somente na área útil da parcela. No momento da colheita, foi determinado o peso úmido dos grãos de cada uma das culturas e retirou-se amostras para determinação da percentagem de umidade, para o cálculo do peso seco.

Para determinação de umidade usou-se a fórmula:

$H_{0}=\mathrm{Pu}-\mathrm{Ps} / \mathrm{Pu} \times 100$

onde:

Ho = umidade das sementes expressa em percentagem 
$\mathrm{Pu}=$ peso das sementes no momento da colheita

$P s=$ peso das sementes secas em estufa a $70^{\circ} \mathrm{C}$

A produção foi determinada com $13 \%$ de umidade para as duas culturas. Para determinar a produção nesta umidade foi utilizada a fórmula:

$P_{f}=P_{0}\left(100-H_{0}\right) /(100-H f)$

onde:

$P_{f}=$ peso das sementes corrigido para $13 \%$ de umidade

$P_{0}=$ peso das sementes no momento da colheita

$\mathrm{H}_{0}=$ percentagem de umidade das sementes

$\mathrm{H}_{\mathrm{f}}=$ percentagem de umidade dese jada (13\%).

\subsection{Predição do crescimento volumétrico da bracatinga}

Para obtenção da estimativa de produção volumétrica a partir do terceiro ano, foi desenvolvida uma equação com dados reais de volume, a partir de medições de altura e DAP em idades sequenciais em um mesmo povoamento. Os dados foram obtidos de diversos povoamentos de regeneração natural e implantados por mudas, existentes na região de ocorrência natural da bracatinga ou próximos dela. os dados de volume dos diversos povoamentos (Tabela 6 ), evidenciou o modelo $y=a x^{b}$ como o mais indicado para representar o crescimento das populações. Na seleção das regressões utilizou-se o coeficiente de determinação $(R 2)$, o teste $F$ e a distribuição de resíduos como parâmetros indicativos da precisão do ajuste. 
Tabela 6 - Localização, idade e espaçamento de bracatingais cujos volumes foram utilizados para determinação da equação de predição de volume.

\begin{tabular}{lllll}
\hline Local & $\begin{array}{l}\text { Idade } \\
\text { (anos) }\end{array}$ & $\begin{array}{l}\text { Espaçamento } \\
\text { Inicial (m) }\end{array}$ & $\begin{array}{l}\text { № de } \\
\text { Parcelas }\end{array}$ & $\begin{array}{l}\text { Modalidade de } \\
\text { Implantação }\end{array}$ \\
\hline Bocaiuva do Sul-PR & 4 a 7 & - & 2 & regeneração natural \\
Colombo-PR & 4 a 7 & - & 2 & regeneração natural \\
Campo Mourão-PR & 1 a 7 & $3 \times 3$ & 4 & mudas \\
Concórdia-SC & 4 a 7 & $2 \times 2$ & 2 & mudas \\
Concórdia-SC & 4 a 7 & $2 \times 2,5$ & 2 & mudas \\
Concórdia- SC & $4 a 7$ & $2,5 \times 2,5$ & 2 & mudas \\
Concórdia-SC & 4 a 7 & $3 \times 2$ & 2 & mudas \\
Concórdia-SC & 4 a 7 & $3 \times 3$ & 2 & mudas \\
\hline
\end{tabular}

Fonte: EMBRAPA-CNPF, dados não publicados.

Com o conjunto de dados apresentados na Tabela 6 testou-se regressões do tipo $Y=a X^{b}$, onde:

$Y=$ volume futuro

$X=$ volume atual, calculado pelo procedimento de AHRENS (1981)

Os volumes das idades de 1 a 7 anos foram pareados para determinação dos coeficientes "a" e "b" das equações.

Com o conjunto de todas as combinações de idade e os valores dos coeficientes ("a" e "b") correspondentes, ajustaram-se modelos de regressão necessários para estimar os coeficientes "a" e "b" conforme a idade atual e a idade requerida. A partir do valor de "a", ajustaram-se os valores de "b" do modelo não linear, após prévia estimativa do mesmo coeficiente, por regressão linear de primeiro grau. Desta forma pode-se expressar ọs valores de"a" e "b" pelas expressões:

$$
\begin{aligned}
& a=a 0+a 1\left(I_{\text {fut }} /\left.\right|_{\text {atual }}\right)^{2} \mathrm{e} \\
& b=b_{0}+b_{1}\left(I_{\text {fut }} /\left.\right|_{\text {atual }}\right) \quad \text { onde: } \\
& \text { Ifut = idade futura } \\
& \text { latual = idade atual } \\
& \text { ao, a1, bo,b1 = coef icientes das regressões }
\end{aligned}
$$


Com os coeficientes "a" e "b" ajustados no modelo não linear, determinou-se a equação para predição volumétrica de povoamentos de bracatinga.

\subsection{Avaliação econômica}

A avaliação econômica foi feita segundo metodologia adotada por GRAÇA \& MENDES (1987), utilizando os critérios Valor Liquido Presente (VLP), Relação Beneficio-Custo (RBC) e Taxa interna de Retorno (TIR).

o VLP fornece o valor futuro das receitas líquidas, descontado para o presente em moeda corrente. Se o valor for maior que zero, o sistema é considerado rentável.

A RBC dá a relação proporcional entre receitas e despesas. Se o resultado for maior que 1 , os benefícios ou receitas serão maiores do que os custos; se menor que 1, os custos serão maiores do que as receitas.

A TIR fornece a taxa de retorno intrínseca dos sistemas aval iados e independe das taxas de juros ou de desconto praticadas no mercado. Se aTIR for maior do que as taxas de mercado, (que) o projeto é potencialmente rentável do ponto de vista ecônomico.

Para determinação de VLP, RBC e TIR foram elaboradas planilhas básicas sobre quantidade de mão-de-obra utilizada em cada fase do sistema tradicional de cultivo da bracatinga, quantidade de insumos e respectivos preços de março de 1993, convertidos em dólar comercial de 15 de março 1993 (Tabelas 7,8 e 9). Os preços foram obtidos na Secretaria de Estado da Agricultura e do Abastecimento,Departamento de Economia Rural, Divisão de Estatísticas Básicas (SEAB-DERAL-DEB-PR) e referem-se a valores médios praticados na Região Metropolitana de Curitiba.

Para a avaliação econômica do tratamento CA considerou-se a produção agrícola, ao longo dos sete anos, idêntica à do primeiro ano. 
Tabela 7 - Mão-de-obra utlizada em cada fase do sistema de cultivo da bracatinga.

OPERAÇÃO Homem dia/ha

1. LIMPEZA

Roçada $\quad 6,3$

2. EXPLORACÃO

Corte/empithamento $\quad 27,7$

Arraste/estaleiramento $\quad 12,9$

$\begin{array}{ll}\text { Milho } & 7,7\end{array}$

Feijão 2,3

3. PLANTIO

Aceiro/queima

1,6

Milho

2,4

Feijão

1,0

4. TRATOS CULTURAIS

Combate a formigas

Duas capinas

0,5

Raleio da bracatinga

Desbaste na cova do milho

Adubação de cobertura

1,0

TOTAL

90,5

Fonte: adaptado de GRAC A \& MENDES (1987) e LAURENT et al.(1990a).

Tabela 8 - Quantidade de insumos ( $\mathrm{Kg} / \mathrm{ha}$ ) utilizados nos tratamentos.

\section{TRATAMENTOS}

INSUMOS

SAT SAM CA SFT SFMI SFM2

Sementes de milho

Semente de feijão

$\begin{array}{cccccc}25 & 36 & 42 & - & - & - \\ 19 & 26,5 & 24,5 & - & - & - \\ 2 & 2 & 2 & 2 & 2 & 2 \\ - & 120 & 120 & - & - & -\end{array}$

SAT-sistema agrof lorestal tradicional, SAM-sistema agroflorestal melhorado, CAculturas agrícolas, SFT-sistema florestal tradicional, SFM1-sistema florestal melhorado 1, SFM2-sistema florestal melhorado 2. 
Tabela 9 - Preços no sistema de cultivo de bracatinga

\begin{tabular}{lcrc}
\hline Produto & Unidade & Valor Cr\$ & Valor em U\$ \\
\hline Salário mínimo & mêc & $1.709 .400,00$ & 77,83 \\
Diária & dia & $77.214,00$ & 3,51 \\
Cavalo(amansado de 5 anos) & uni & $3.668 .717,75$ & 167,04 \\
Zorra & uni & $878.520,00$ & 40,00 \\
Terra não mecanizável & ha & $3.000 .000,00$ & 136,59 \\
Sementes de milho & $\mathrm{Kg}$ & $24.500,00$ & 1,11 \\
Sementes de feijão & $\mathrm{Kg}$ & $17.040,00$ & 0,77 \\
Superfosfato simples & $\mathrm{Kg}$ & $2.954,00$ & 0,13 \\
Uréia & $\mathrm{Kg}$ & $4.985,00$ & 0,22 \\
Milho em grão & $\mathrm{Kg}$ & $3.650,00$ & 0,16 \\
Feijão em grão & $\mathrm{Kg}$ & $5.916,67$ & 0,26 \\
Formicida Mirex & $\mathrm{K} / \mathrm{Kg}$ & $27.000,00$ & 1,22 \\
Lenha no carreador & $\mathrm{st}$ & $100.000,00$ & 4,55 \\
\hline
\end{tabular}

Fonte: SEAB/DERAL/DEB-PR. Preços de março de 1993, convertidos ao dólar de 15 de março de 1993, no valor de $\operatorname{Cr} \$ 21.963,00$ 


\section{RESULTADOS}

\subsection{Densidade da bracatinga}

A Tabela 10 apresenta a intensidade de desbaste aplicada aos tratamentos e o número de plantas que restaram após o desbaste. A densidade antes do desbaste reflete a erradicação diferenciada de plantas, nos tratamentos com capinas. No tratamento SFT, onde não foram realizadas capinas, a quantidade de plantas foi maior.

Tabela 10 - Densidade da bracatinga antes e após desbaste aos 4 meses de idade e intensidade de desbaste. Média das parcelas dos tratamentos.

\begin{tabular}{lccc}
\hline Tratamentos & \multicolumn{2}{c}{ Plantas/ha } & $\begin{array}{c}\text { Intensidade do } \\
\text { desbaste(\%) }\end{array}$ \\
\cline { 2 - 3 } & $\begin{array}{l}\text { Antes do } \\
\text { desbaste }\end{array}$ & $\begin{array}{l}\text { Após o } \\
\text { desbaste }\end{array}$ & \\
\hline Sistema agroflorestal tradicional-SAT & 8681 & 8681 & 0 \\
Sistema agrof lorestal melhorado-SAM & 15069 & 8472 & 43 \\
Sistema florestal tradicional-SFT & 30833 & 30833 & 0 \\
Sistema florestal melhorado 1-SFM1 & 17778 & 9653 & 45 \\
Sistema florestal melhorado 2-SFM2 & 8125 & 3333 & 60 \\
\hline
\end{tabular}

Os dados de germinação de plantas após a primeira capina são apresentados na Tabela 11 e ilustrados na Figura 4. Eles revelam que um número considerável de plantas germinou após a primeira capina. 
Tabela 11 - Número de plantas de bracatinga aos 60 dias, nascidas antes e após a primeira capina.

\begin{tabular}{lcc}
\hline Tratamentos & \multicolumn{2}{c}{ Plantas/ha } \\
\cline { 2 - 3 } & Antes da primeira capina & Após a primeira capina \\
\hline Sistema agrof lorestal tradicional-SAT & 5740 & 4999 \\
Sistema agrof lorestal melhorado-SAM & 5902 & 9166 \\
Sistema florestal melhorado 1-SFM1 & 13055 & 4374 \\
Sistema florestal melhorado 2-SFM2 & 3680 & 4652 \\
\hline
\end{tabular}

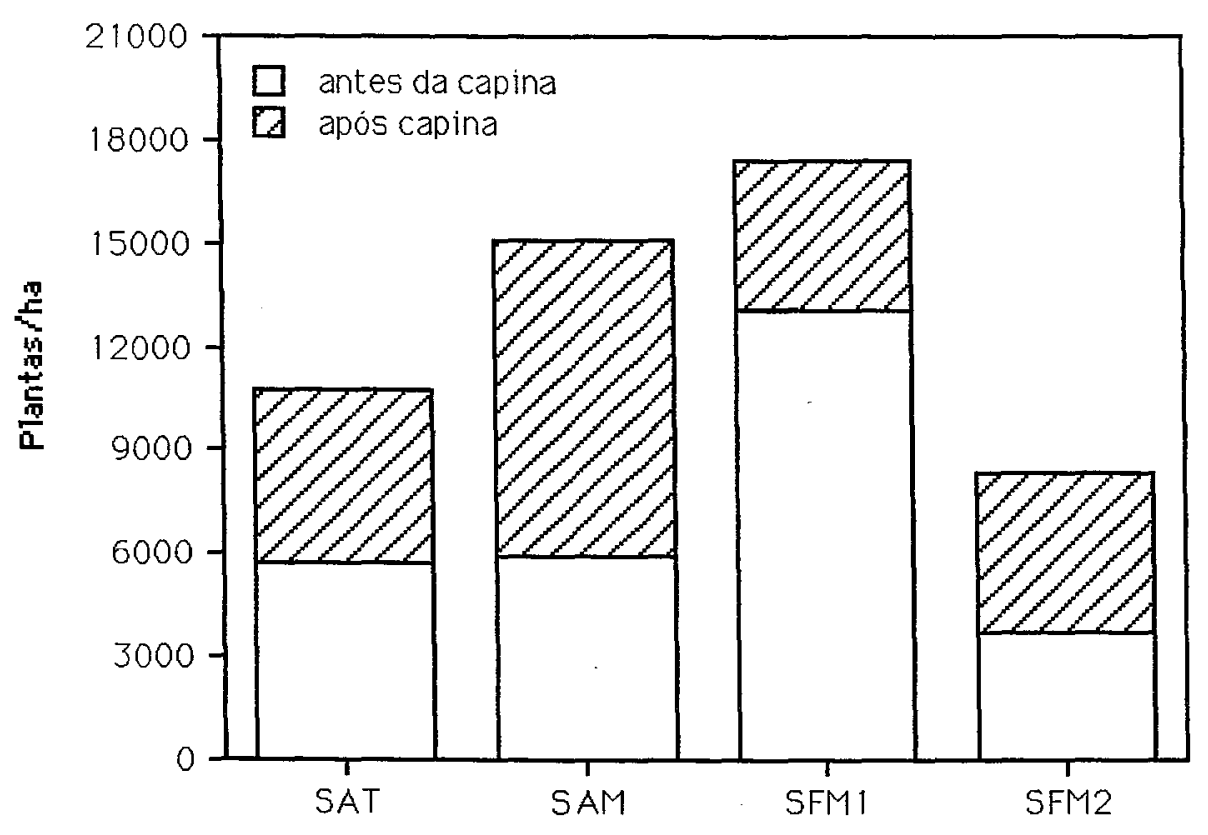

Figura 4 - Número de plantas de bracatinga nascidas antes e após a primeira capina, por tratamento. SAT-sistema agroflorestal tradicional, SAM-sistema agroflorestal meihorado, SFM1-sistema florestal melhorado 1 e SFM2sistema florestal melhorado 2.

A Tabela 12 apresenta a evolução da densidade após o desbaste. Em todos os tratamentos, a maior mortalidade foi observada até o 150 mes de idade. Nos tratamentos com desbaste, a mortalidade média até o 290 mes situa-se entre 12 e $24 \%$. No tratamento SFT, onde não houve interferência humana após a queima, a mortalidade 
observada até o 290 mes de idade atingiu 57\%. A Figura 5 ilustra os dados apresentados na Tabela 12.

Tabela 12 - Densidade da bracatinga aos 4, 15, 20 e 29 meses de idade. Média das parcelas dos tratamentos

\begin{tabular}{lccccc}
\hline Tratamentos & \multicolumn{4}{c}{ Plantas/ha } & $\begin{array}{l}\text { Mortalidade aos } \\
29\end{array}$ \\
\cline { 2 - 4 } & 4 meses & 15 meses & 20 meses & 29 meses & \\
\hline SAT & 8681 & 6181 & 6042 & 5486 & 36 \\
SAM & 8472 & 8125 & 7917 & 7430 & 12 \\
SFT & 30833 & 16042 & 15069 & 13194 & 57 \\
SFM1 & 9653 & 7847 & 7569 & 7291 & 24 \\
SFM2 & 3333 & 3194 & 3056 & 2916 & 12
\end{tabular}

SAT-sistema agroflorestal tradicional, SAM-sistema agroflorestal melhorado, SFT-sistema florestal tradicional, SFM1-sistema florestal melhorado 1, SFM2-sistema florestal melhorado 2

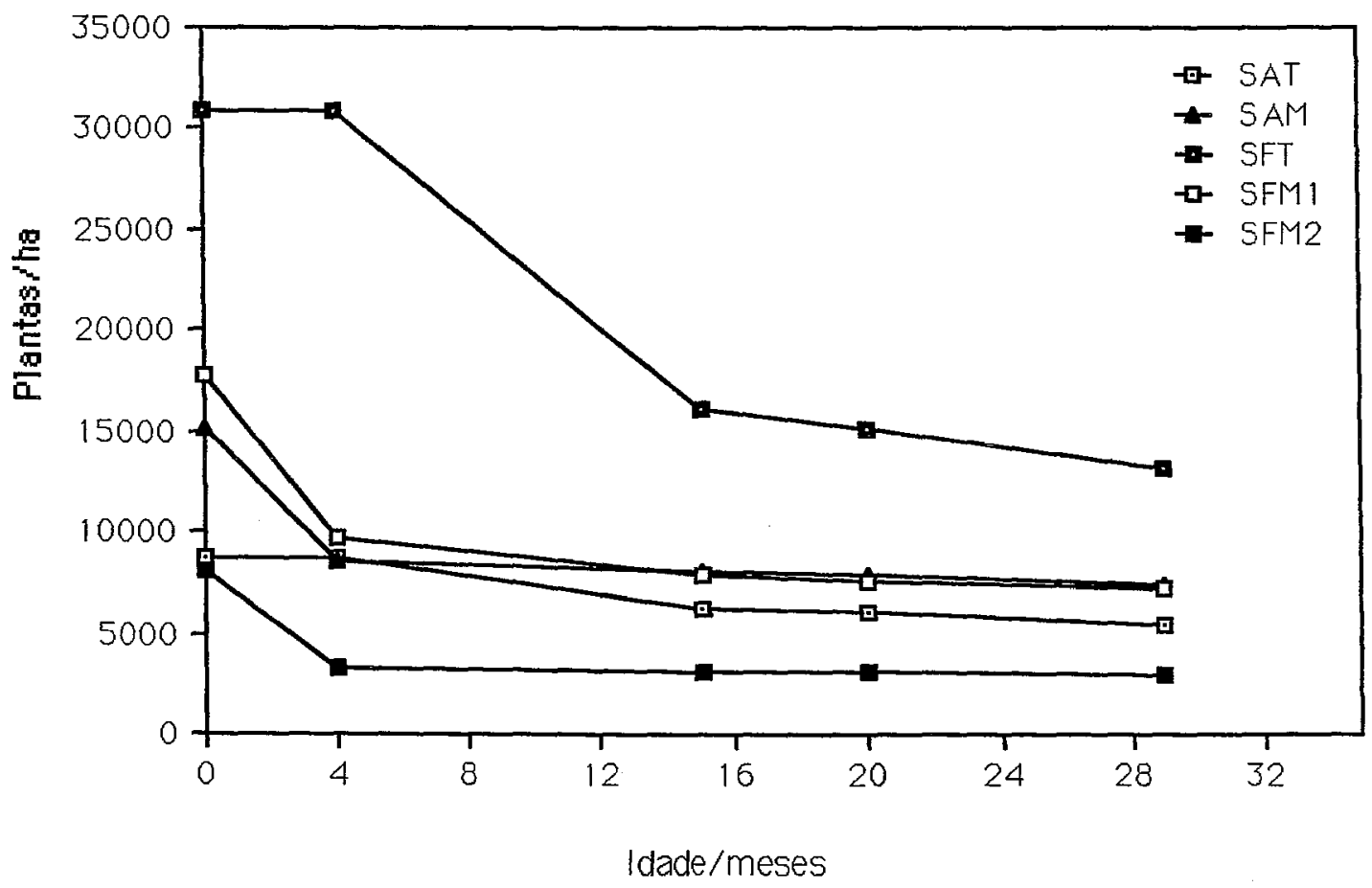

Figura 5. Evo lução da densidade da bracatinga após a queima. Média das parcelas dos tratamentos. A idade zero refere-se aos 4 meses de idade, antes do desbaste. SAT-sistema agroflorestal tradicional, SAM-sistema agroflorestal melhorado, SFT-sistema florestal tradicional, SFM1-sistema florestal melhorado 1 e SFM2-sistema florestal melhorado 2. 


\section{2. Crescimento da bracatinga}

\subsubsection{Crescimento em altura e diâmetro}

Os resultados apresentados na Tabela 13 e 14 mostram que 0 tratamento SFM1, no inicio, apresentou superioridade significativa sobre os demais tratamentos mas, na ultima medição, igualou-se ao SAT e SFM2 em altura. Seu diâmetro igualou-se ao do tratamento SFM2 a partir do $15^{\circ}$ mes e ao SAT na medição final. No tratamento SFT, no qual não foram realizados tratos culturais, o crescimento em diâmetro e altura foi inferior aos demais tratamentos.

Tabela 13 - Altura da bracatinga aos 4, 15, 20 e 29 meses de idade.

\begin{tabular}{|c|c|c|c|c|}
\hline \multirow[t]{2}{*}{ Tratamentos } & \multicolumn{3}{|c|}{ Altura(m) } & \multirow[b]{2}{*}{29 meses } \\
\hline & 4 meses* & 15 meses & 20 meses & \\
\hline Sistema agroflorestal tradicional-SAT & $0,60 \mathrm{c}$ & $2,36 \mathrm{c}$ & $3,98 b$ & $5,76 \mathrm{ab}$ \\
\hline Sistema agroflorestal melhorado-SAM & $0,70 \mathrm{c}$ & $2,31 \mathrm{C}$ & $3,87 b$ & $5,52 b$ \\
\hline Sistema fiorestal tradicional-SFT & $0,32 d$ & $1,17 d$ & $2,41 \mathrm{c}$ & $3,83 \mathrm{c}$ \\
\hline Sistema florestal melhorado I-SFM1 & $1,23 a$ & $3,31 \mathrm{a}$ & $4,78 \mathrm{a}$ & $6,07 a$ \\
\hline Sistema florestal melhorado 2-SFM2 & $0,98 b$ & $2,64 b$ & $4,22 b$ & $5,96 a b$ \\
\hline Coeficiente de variação \% & 50,13 & 32,43 & 28,27 & 25,88 \\
\hline
\end{tabular}

Médias seguidas por letras diferentes significam diferenças significativas dentro da mesma idade, ao nivel de.5\% pelo teste Tukey.

* após o desbaste 
Tabela 14 - Diâmetro da bracatinga aos 4, 15, 20 e 29 meses de idade.

\begin{tabular}{lllll}
\hline Tratamentos & \multicolumn{4}{c}{ Diâmetro $(\mathrm{cm})$} \\
\cline { 2 - 5 } & 4 meses* & 15 meses & 20 meses & 29 meses \\
\hline Sistema agrof lorestal tradicional-SAT & $0,43 \mathrm{c}$ & $1,82 \mathrm{~b}$ & $2,52 \mathrm{~b}$ & $4,02 \mathrm{bc}$ \\
Sistema agrof lorestal melhorado-SAM & $0,44 \mathrm{c}$ & $1,73 \mathrm{~b}$ & $2,40 \mathrm{~b}$ & $3,66 \mathrm{c}$ \\
Sistema florestal tradicional-SFT & $0,19 \mathrm{~d}$ & $0,83 \mathrm{c}$ & $1,18 \mathrm{c}$ & $2,15 \mathrm{~d}$ \\
Sistema florestal melhorado 1-SFM1 & $0,92 \mathrm{a}$ & $2,54 \mathrm{a}$ & $3,29 \mathrm{a}$ & $4,32 \mathrm{ab}$ \\
Sistema florestal melhorado 2-SFM2 & $0,69 \mathrm{~b}$ & $2,95 \mathrm{a}$ & $3,48 \mathrm{a}$ & $5,03 \mathrm{a}$ \\
Coeficiente de variação $\%$ & 42,31 & 43,90 & 47,01 & 40,85 \\
\hline
\end{tabular}

* diâmetro medido a $10 \mathrm{~cm}$ do solo, após o desbaste.

Médias seguidas por letras diferentes significam diferenças significativas dentro da mesma idade, ao nivel de 5\% pelo teste Tukey.

\subsubsection{Crescimento em área basal e volume}

Nas Tabelas 15 e 16 são apresentados os resultados obtidos para área basal e para volume cilíndrico individual. Aos 29 meses, os tratamentos SFM1 e SFM2 diferiram entre si em área basal e volume. O tratamento SFT apresentou, significativamente, o menor valor para volume cilíndrico individual.

Tabela 15 - Area basal da bracatinga aos 4, 15, 20 e 29 meses de idade.

\begin{tabular}{lllcc}
\hline Tratamentos & \multicolumn{4}{c}{ Area basal $\left(\mathrm{m}^{2} / \mathrm{ha}\right)$} \\
\cline { 2 - 5 } & 4 meses* $^{*}$ & 15 meses & 20 meses & 29 meses \\
\hline Sistema agroflorestal tradicional SAT & $0,17 \mathrm{c}$ & $1,55 \mathrm{~b}$ & $5,80 \mathrm{ab}$ & $7,99 \mathrm{~b}$ \\
Sistema agrof lorestal melhorado SAM & $0,18 \mathrm{c}$ & $2,05 \mathrm{~b}$ & $4,30 \mathrm{ab}$ & $9,30 \mathrm{ab}$ \\
Sistema florestal tradicional SFT & $0,04 \mathrm{~d}$ & $1,27 \mathrm{~b}$ & $2,00 \mathrm{~b}$ & $6,62 \mathrm{~b}$ \\
Sistema florestal melhorado 1 SFM1 & $0,73 \mathrm{a}$ & $4,30 \mathrm{a}$ & $7,13 \mathrm{a}$ & $12,35 \mathrm{a}$ \\
Sistema florestal melhorado 2 SFM2 & $0,41 \mathrm{~b}$ & $1,33 \mathrm{~b}$ & $3,27 \mathrm{ab}$ & $6,66 \mathrm{~b}$ \\
Coeficiente de variação \% & 87,73 & 29,74 & 43,22 & 19,39 \\
\hline
\end{tabular}

* diâmetro medido a $10 \mathrm{~cm}$ do solo, após o desbaste

Médias seguidas por letras diferentes significam diferenças significativas dentro da mesma idade, ao nivel de.5\% pelo teste Tukey. 
Tabela 16 - Volume cilindrico individual da bracatinga aos 15, 20 e 29 meses de idade

\begin{tabular}{llll}
\hline Tratamentos & \multicolumn{3}{c}{ Volume cilindrico (m²arvore) } \\
\cline { 2 - 4 } & 15 meses & 20 meses & 29 meses \\
\hline Sistema agrof lorestal tradicional-SAT & $0,00093 \mathrm{~b}$ & $0,00289 \mathrm{~b}$ & $0,00960 \mathrm{bc}$ \\
Sistema agrof lorestal melhorado-SAM & $0,00082 \mathrm{~b}$ & $0,00248 \mathrm{~b}$ & $0,00799 \mathrm{C}$ \\
Sistema florestal tradicional-SFT & $0,00014 \mathrm{C}$ & $0,00052 \mathrm{C}$ & $0,00276 \mathrm{~d}$ \\
Sistema florestal melhorado 1-SFM1 & $0,00193 \mathrm{a}$ & $0,00476 \mathrm{a}$ & $0,01118 \mathrm{~b}$ \\
Sistema florestal melhorado 2-SFM2 & $0,00160 \mathrm{a}$ & $0,00562 \mathrm{a}$ & $0,01582 \mathrm{a}$ \\
Coeficiente de variação \% & 32,43 & 96,07 & 70,84 \\
\hline
\end{tabular}

Médias seguidas por letras diferentes significam diferenças significativas dentro da mesma idade, ao nivel de.5\% pelo teste Tukey.

A Tabela 17 e a Figura 6 apresentam o crescimento em volume cilindrico por hectare; aos 29 meses o tratamento SFM1 superou os tratamentos SFT e SFM2 e houve igualdade estatística com os demais tratamentos.

Tabela 17 - Volume cilindrico por área da bracatinga aos 15, 20 e 29 meses de idade

\begin{tabular}{lccc}
\hline Tratamentos & \multicolumn{3}{c}{ volume cilíndrico $\left(\mathrm{m}^{3} / \mathrm{ha}\right)$} \\
\cline { 2 - 4 } & 15 meses & 20 meses & 29 meses \\
\hline Sistema agroflorestal tradicional-SAT & $4,78 \mathrm{~b}$ & $27,32 \mathrm{ab}$ & $52,43 \mathrm{ab}$ \\
Sistema agroflorestal melhorado-SAM & $5,97 \mathrm{~b}$ & $19,14 \mathrm{ab}$ & $58,73 \mathrm{ab}$ \\
Sistema florestal tradicional-SFT & $2,27 \mathrm{~b}$ & $7,07 \mathrm{~b}$ & $33,66 \mathrm{~b}$ \\
Sistema florestal melhorado 1-SFM1 & $15,21 \mathrm{a}$ & $36,03 \mathrm{a}$ & $81,44 \mathrm{a}$ \\
Sistema florestal melhorado 2-SFM2 & $4,46 \mathrm{~b}$ & $16,40 \mathrm{ab}$ & $46,08 \mathrm{~b}$ \\
Coeficiente de variação \% & 36,18 & 43,31 & 25,60 \\
\hline
\end{tabular}

Médias seguidas por letras diferentes signif icam diferenças significativas dentro da mesma idade, ao nivel de.5\% pelo teste Tukey 


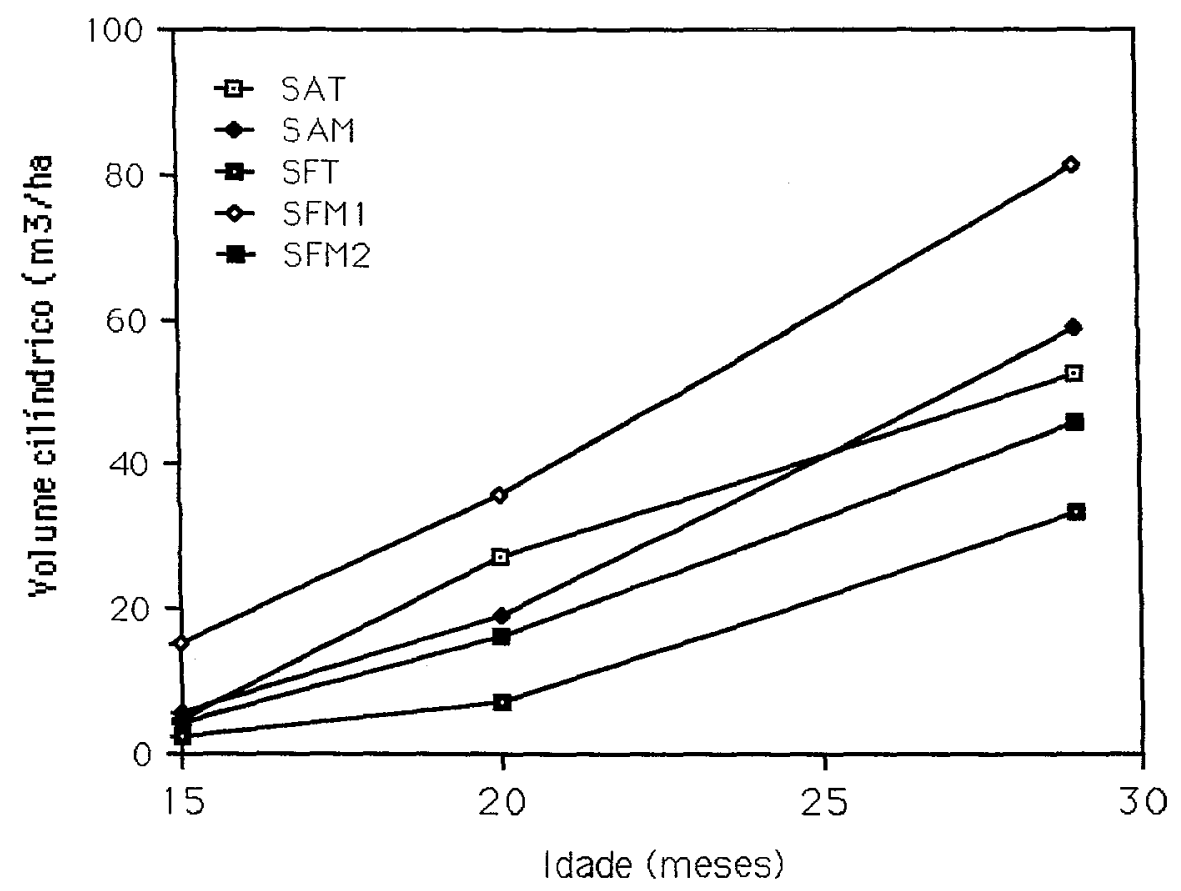

Figura 6 - Evolução temporal de volume da bracatinga em função dos tratamentos. SATsistema agroflorestal tradicional, SAM-sistema agrof lorestal melhorado, SFT-sistema florestal tradicional, SFMI-sistema florestal melhorado 1, SFM2-sistema florestal melhorado 2.

\subsection{Equação para predição de crescimento volumétrico da bracatinga}

Na Tabela 18 estão apresentados os coeficientes "a" e "b" e os coeficientes de determinação obtidos para a equação de predição volumétrica. 
Tabela 18 - Coeficientes "a" e "b" e coeficiente de determinação $R^{2}$ obtidos pela regressão $Y=a X^{b}$.

\begin{tabular}{|c|c|c|c|}
\hline Pares de Idade & Coeficiente a & Coeficiente $b$ & $\mathrm{R} 2(\%)$ \\
\hline $1-7$ & 51,9988792 & 0,5140642 & 65,07 \\
\hline $1-6$ & 45,3302765 & 0,5207746 & 60,53 \\
\hline $1-5$ & 52,3375635 & 0,3904802 & 60,52 \\
\hline $1-4$ & 42,1373849 & 0,3376529 & 60,30 \\
\hline $1-3$ & 28,3629606 & 0,5174816 & 98,22 \\
\hline $1-2$ & 16,9506867 & 0,5172131 & 96,33 \\
\hline $2-3$ & 2,0494994 & 0,9371254 & 98,8 \\
\hline $2-4$ & 5,6243246 & 0,7048930 & 73,17 \\
\hline $2-5$ & 5,3389158 & 0,8003618 & 70,45 \\
\hline $2-6$ & 2,1539293 & 1,0685424 & 72,92 \\
\hline $2-7$ & 2,5539649 & 1,0564190 & 79,68 \\
\hline $3-4$ & 3,8379307 & 0,7100828 & 73,27 \\
\hline $3-5$ & 3,3491343 & 0,8150059 & 72,23 \\
\hline $3-6$ & 1,1929461 & 1,0794199 & 72,93 \\
\hline $3-7$ & 1,4843943 & 1,0562572 & 77,53 \\
\hline $4-5$ & 2,8616185 & 0,7835896 & 88,96 \\
\hline $4-6$ & 3,9161709 & 0,7146468 & 86,93 \\
\hline $4-7$ & 4,1956619 & 0,7114275 & 89,49 \\
\hline $5-6$ & 1,7718629 & 0,8773264 & 92,54 \\
\hline $5-7$ & 1,7648190 & 0,8882840 & 94,53 \\
\hline $6-7$ & 1,0324400 & 1,0027377 & 97,84 \\
\hline
\end{tabular}

Os coeficientes "a" e "b" podem ser estimados, com razoável precisão, pelas equações seguintes:

$$
\begin{array}{ll}
a=2,13442+1,30815 *\left(I_{\text {fut }} / \text { latual }^{2}\right. & R^{2}=83,84 \% \\
b=0,83572-0,11625 *\left(I_{\text {fut }} / \text { latual }\right) & R^{2}=74,38 \%
\end{array}
$$


Substituindo-se os coeficientes na equação para predição de volume de bracatinga e reajustando-se o modelo não linear com os novos valores de "a" e "b" obteve-se a nova equação:

$v_{\text {fut }}=2,0055+0,701\left(\text { f }_{\text {fut }} / \text { latual }^{2}\right)^{2} v_{\text {atual }} 0,8618-0,7711$ (lfut/latual $)$

$R^{2}=90,42 \%$

onde:

Vfut $=$ volume futuro

Ifut $=$ idade futura

latual $=$ idade atual

$\checkmark$ atual $=$ volume atual

Com a fórmula desenvolvida para determinação do volume, foi feita a predição do volume em todos os sistemas estudados, até o 70 ano (Tabela 19 e Figura 7).

Tabela 19 - Volumes sólidos em pé com casca previstos até os sete anos, calculados pela fórmula de predição desenvolvida neste trabalho.

\begin{tabular}{lllllll}
\hline Tratamentos & \multicolumn{7}{c}{ volume $\left(\mathrm{m}^{3 / h a}\right)$} \\
\cline { 2 - 7 } & 29meses* 3anos & 4anos & 5 anos & 6 anos & 7anos \\
\hline SAT & 25,69 & 37,11 & 42,57 & 48,95 & 55,78 & 62,70 \\
SAM & 28,77 & 40,48 & 46,27 & 53,01 & 60,19 & 67,41 \\
SFT & 16,49 & 26,43 & 30,75 & 35,86 & 41,44 & 47,24 \\
SFM1 & 39,90 & 52,01 & 58,83 & 66,70 & 74,94 & 83,06 \\
SFM2 & 22,57 & 33,62 & 38,72 & 44,71 & 51,15 & 57,73 \\
\hline
\end{tabular}

* Volume aos 29 meses obtido pelo procedimento de AHRENS (1981). SAT- sistema agroflorestal tradicional, SAM- sistema agroflorestal melhorado, SFT- sistema florestal tradicional, SFM1-sistema florestal melhorado 1, SFM2- sistema florestal melhorado 2. 


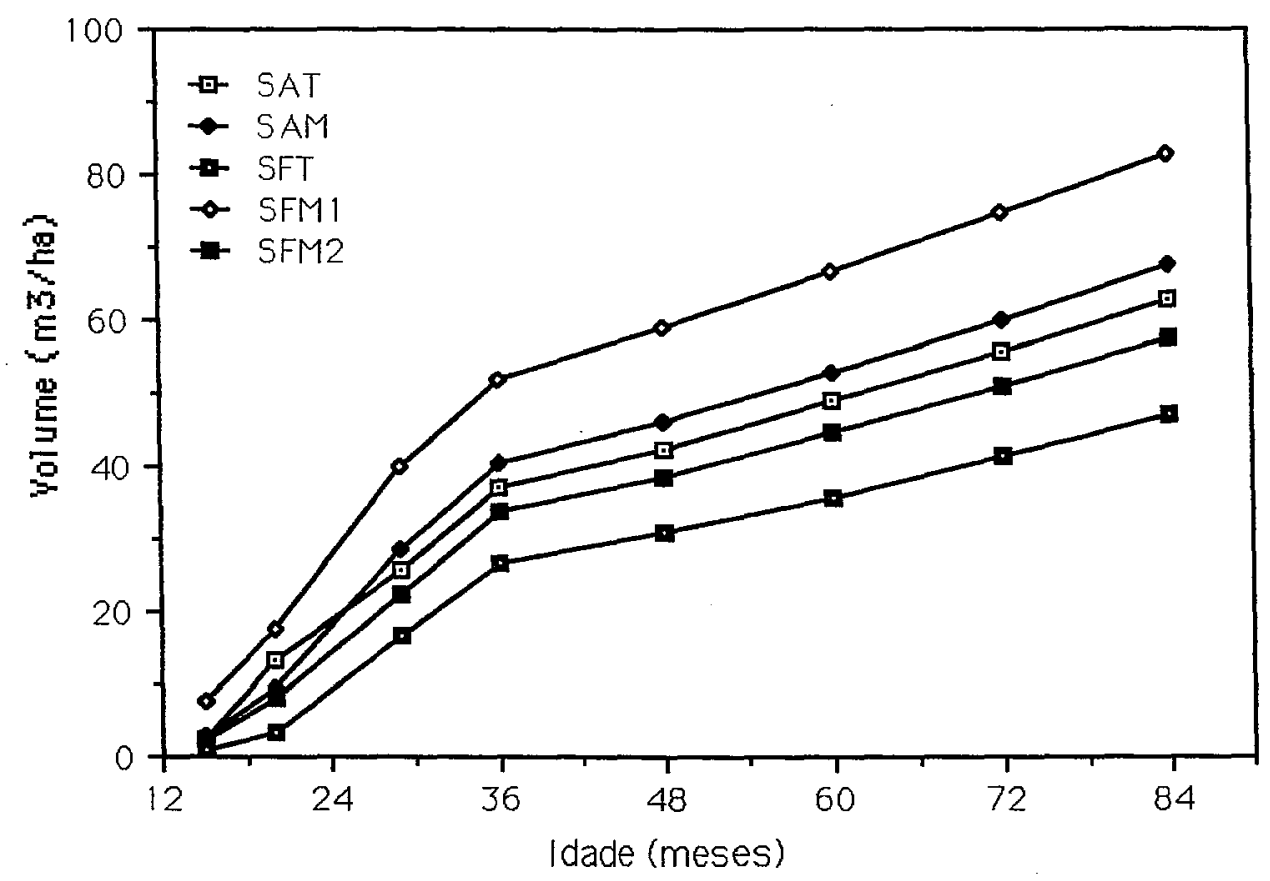

Figura 7 - Volume de bracatinga nos tratamentos até 84 meses de idade. Até 29 meses: média das parcelas experimentais. Após 29 meses: estimativa pela equação de predição desenvolvida. SAT-sistema agroflorestal tradicional, SAMsistema agroflorestal melhorado, SFT-sistema florestal tradicional, SFM1sistema florestal melhorado 1 e SFM2-sistema florestal melhorado 2.

A predição de volume empilhado de lenha, aos 7 anos, é apresentada na Tabela 20. A adoção do valor 1,75 para o fator de empilhamento baseou-se em CARPANEZZI et al. (1988). A unidade de comercialização da lenha, na região, é o MCL - metro comercial de lenha, onde os toretes têm em média 0,74 m de comprimento, gerando o fator de conversão 1 st $=1,35 \mathrm{MCL}$ (LAURENT \& MENDONÇA, 1989; LAURENT et al., 1990a). 
Tabela 20 - Produção de lenha por hectare, aos 7 anos de idade, estimado a partir da fórmula de predição de volume desenvolvida. Fator de empilhamento = 1,75. Fator de conversão de st para metro comercial de lenha $(M C L)=$ 1,35 .

\begin{tabular}{lllllll}
\hline Tratamentos & \multicolumn{3}{c}{ Volume } & & \multicolumn{2}{c}{ IMA } \\
\cline { 2 - 3 } \cline { 6 - 7 } & $\mathrm{m} 3 / \mathrm{ha}$ & st/ha & MCL & & $\mathrm{m} 3 / \mathrm{ha}$ & st/ha \\
\hline SAT & 62,70 & 109,72 & 147,97 & 8,95 & 15,67 \\
SAM & 67,41 & 117,96 & 159,08 & 9,63 & 16,85 \\
SFT & 47,24 & 82,67 & 111,48 & 6,74 & 11,81 \\
SFM1 & 83,06 & 145,35 & 196,02 & 11,86 & 20,76 \\
SFM2 & 57,73 & 101,02 & 136,24 & 8,24 & 14,43 \\
\hline
\end{tabular}

SAT-sistema agroflorestal tradicional, SAM-sistema agroflorestal melhorado, SFT-sistema florestal tradicional, SFM1-sistema florestal melhorado 1, SFM2-sistema florestal melhorado 2.

\subsection{Rendimento das culturas agricolas}

Os rendimentos do mi tho e feijão nos tratamentos consorciados com a bracatinga são apresentados na Tabela 21. O cultivo do milho e feijão foi feito somente no primeiro ano, como é praxe no sistema tradicional de cultivo de bracatinga, praticado pelos agricultores. Os tratamentos SAM e CA foram adubados, todavia não houve resposta de produtividade. Comparados, os tratamentos apresentam diferença significativa somente para produtividade do milho. 
Tabela 21 - Produtividades de mi tho e feijão

\begin{tabular}{lccccc}
\hline Tratamentos & \multicolumn{2}{c}{ Milho } & & \multicolumn{2}{c}{ Feijão } \\
\cline { 2 - 3 } & $\mathrm{Kg} / \mathrm{ha}$ & Covas/ha & & $\mathrm{Kg} / \mathrm{ha}$ & Covas/ha \\
\hline Sistema agroflorestal tradicional-SAT & $761,65 \mathrm{~b}$ & 14000 & & $123,07 \mathrm{a}$ & 20000 \\
Sistema agroflorestal melhorado-SAM & $599,13 \mathrm{~b}$ & 21000 & & $233,66 \mathrm{a}$ & 31000 \\
Culturas agricolas-CA & $1369,19 \mathrm{a}$ & 42000 & & $216,79 a$ & 29000 \\
Coeficiente de variação $\%$ & 32,71 & & & 32,27 & \\
\hline
\end{tabular}

Médias seguidas por letras diferentes significam diferenças significativas dentro da mesma idade, ao nivel de.5\% pelo teste Tukey

\subsection{Avaliação econômica}

Os valores obtidos de Valor Líquido Presente (VLP), Relação Beneficio-Custo (RBC) e Taxa Interna de Retorno (TIR) são apresentados nas Tabelas 22 e 23 , para taxas de 6,8 e $10 \%$.

Tabela 22 - Valor Liquido Presente (VLP) para sistemas florestais e agroflorestais de bracatinga e para plantio de mitho com feijão. Taxas de desconto de 6,8 e $10 \%$.

\begin{tabular}{llll}
\hline Tratamentos & \multicolumn{3}{l}{ VLP (dólar/ha) } \\
\cline { 2 - 4 } & $6 \%$ & $8 \%$ & $10 \%$ \\
\hline Sistema agroflorestal tradicional-SAT & 291,52 & 256,28 & 225,37 \\
Sistema agrof lorestal melhorado-SAM & 272,21 & 233,20 & 198,96 \\
Culturas agrícolas-CA & 205,98 & 195,73 & 186,42 \\
Sistema florestal tradicional-SFT & 191,24 & 168,43 & 148,43 \\
Sistema florestal melhorado 1-SFM1 & 371,19 & 319,59 & 274,31 \\
Sistema florestal meihorado 2-SFM2 & 179,31 & 148,07 & 120,66 \\
\hline
\end{tabular}


Tabela 23 - Relação Benefício-Custo (RBC) e Taxa Interna de Retorno (TIR) para sistemas florestais e agroflorestais de bracatinga e para plantio de mitho com feijão. Taxas de desconto de 6,8 e $10 \%$.

\begin{tabular}{llllc}
\hline Tratamentos & \multicolumn{3}{c}{ RBC } & TIR \\
\cline { 2 - 4 } & $6 \%$ & $8 \%$ & $10 \%$ & (\%) \\
\hline Sistema agroflorestal tradicional-SAT & 1,84 & 1,78 & 1,71 & 52,33 \\
Sistema agrof lorestal melhorado-SAM & 1,67 & 1,60 & 1,53 & 33,35 \\
Culturas agricolas-CA & 1,13 & 1,13 & 1,13 & - \\
Sistema florestal tradicional-SFT & 2,14 & 2,11 & 2,07 & 56,75 \\
Sistema florestal melhorado 1-SFM1 & 2,43 & 2,31 & 2,19 & 35,25 \\
Sistema florestal methorado 2-SFM2 & 1,69 & 1,60 & 1,52 & 24,15 \\
\hline
\end{tabular}




\section{DISCUSSÃO}

\subsection{Densidade da bracatinga}

A densidade da bracatinga na área experimental foi inferior aos valores esperados, relatados por CARPANEZZl et al. (1988) e CARPANEZZI (1989), para o sistema tradiciona\}. Isto não permitiu desbaste, aos quatro meses, de todos os tratamentos previstos. Assim, a intensidade de desbaste foi diferenciada nos tratamentos (Tabela 10). Presume-se que as baixas densidades observadas resultaram da erradicação excessiva de plântulas no raleio, executado pelo proprietário na primeira cap ina, segundo seus critérios. O tratamento SAT, por sua densidade baixa, não foi desbastado aos quatro meses como os demais tratamentos previstos, nos quais a seleção atingiu aproximadamente $50 \%$ das plantas (Tabela 10 ).

Nas parcelas do tratamento SFT, sem capinas, foi observada a invasão, principalmente, de duas espécies herbáceas, catirinete (Ambrosia polystachia, Compositae) e capim-rabudo (Setaria verticillata, Gramineae). Estas invasoras apareceram nas parcelas com alta frequência e densidade, especialmente no início do cultivo da bracatinga, exercendo forte competição potencial por água, luz e nutrientes. Observou-se que, onde havia predominância do catirinete, havia pouco ou nenhum capim-rabudo.

Segundo LORENZI (1991), o capim-rabudo é uma graminea anual herbácea com 30 a $50 \mathrm{~cm}$ de altura, com reprodução por sementes. A gramínea, por ser anual e susceptivel a geadas, mantém competição só no início do desenvolvimento da bracatinga, ao passo que o catirinete, perene, mantém competição por periodo prolongado.

O catirinete é uma planta perene, subarbustiva, com até $2 \mathrm{~m}$ de altura, que propaga-se por sementes e vegetativamente por rizomas profundos, tendo 
preferência por solos argilosos (LEITÃo FILHO et al., 1982; LORENZI, 1991). Na área experimental as plantas de catirinete eram, claramente, oriundas de sementes as quais são facilmente dispersadas pelo vento. O solo local é argiloso (Tabela 4), o que favorece a espécie.

Em algumas parcelas do tratamento SFT, no início do cultivo da bracatinga o catirinete era a espécie predominante na vegetação. Sua densidade média, em março de 1991, foi avaliada em $1137 \mathrm{mil}$ plantas/ha, em julho de 1991 era de $256 \mathrm{mil} \mathrm{plantas/ha} \mathrm{e} \mathrm{em} \mathrm{abril} \mathrm{de} 1992$ era de $207 \mathrm{mil} \mathrm{plantas/ha.} \mathrm{A} \mathrm{altura} \mathrm{média} \mathrm{era}$ de 1,30m em março de 1991, sombreando intensamente a bracatinga (comparar com Tabela 13, tratamento SFT, idade de 4 meses). Na aval iação final da bracatinga, aos 29 meses, o catirinete ainda persistia, entretanto com densidade menor.

Os resultados obtidos no tratamento SFT evidenciam que a omissão de capinas prejudicou o crescimento da bracatinga e induziu a al ta mortalidade da espécie (Figura 5 e Tabela 13). Este comportamento concorda com as colocações de VAZQUEZ-YANES (1980) sabre as dificuldade de estabelecimento e crescimento de espécies pioneiras arbóreas em clareiras, em razão da competição exercida pelas espécies herbáceas e ervas daninhas, as quais apresentam maior velocidade de crescimento

No sistema tradicional, normalmente, os produtores realizam um raleio intenso da bracatinga na primeira capina das culturas agricolas. A segunda capina pode conter algum raleio adicional mas é feita principalmente para a amontoa do milho. Com frequência, faz-se apenas uma capina com ambas as finalidades, por motivos climáticos ou escassez de mão-de-obra.

Pelas informações dos produtores, são deixadas em torno de dez mil plantas/ha de bracatinga na primeira capina. Depois dela, porém, germinam muitas sementes ainda existentes no banco (Tabela 11). Assim, deve-se considerar que a heterogeneidade entre plantas dentro de bracatingais do sistema tradicional tem, além do componente genético, este forte componente ambiental decorrente de manejo. Ademais, a desuniformidade da distribuição espacial dos resíduos no terreno provoca, de modo correspondente, mineralização de quantidades diferenciadas de nutrientes pela 
queima, com reflexos potenciais sobre o crescimento das plantas de bracatinga. Este fato é comum nos terrenos de agricultura migratória, como observa FORESTA (1984).

Para a formação de bracatingais de regeneração induzida, 0 preparo do solo através de queima de resíduos de exploração tem um papel dúbio. A queima, ao mesmo tempo que favorece a germinação das sementes de bracatinga contidas no banco, pela interrupção da dormência, elimina grande parte delas, especialmente as presentes nas camadas superficiais.

Em um experimento simulando a queima de residuos no campo, ROTH (1982) observou que as sementes situadas entre 0 e $2 \mathrm{~cm}$ de profundidade perderam completamente a viabilidade com a passagem do fogo, e as contidas entre 2 e 8 $\mathrm{cm}$ permaneceram viáveis. Assim, as sementes mais profundas seriam as formadoras do novo bracatingal. Segundo Carneiro et al. ${ }^{1}$ citado por DIAS et al. (1981), a emergência de plântulas de bracatinga é satisfatória para sementes colocadas até, aproximadamente, $6 \mathrm{~cm}$ de profundidade no solo. Deste modo, a capina, principaimente em solos argilosos como o do experimento, tem o papel potencial de expor as sementes contidas nas camadas mais profundas e facilitar sua germinação, com quebra de dormências pela insolação.

Embora os resultados demonstrem a germinação de novas sementes após a primeira capina (Tabela 11 ), não se sabe ao certo se a germinação é consequência da exposição do banco pela capina ou germinação tardia de sementes profundas. Por outro lado, a alta densidade de bracat inga constatada no tratamento SFT demonstra que, mesmo sem capina, grande quantidade de sementes germinam. Para aclarar o assunto, novas pesquisas são necessárias.

O raleio realizado no sistema tradicional, durante as capinas dos cultivos agrícolas, é insuf iciente, devido ao número de plantas deliberadamente deixadas e a germinação de novas sementes. Nos tratamentos SAM e SFM1, em que houve desbaste pós-capinas, aos 4 meses, para redução da densidade inicial da bracatinga, ainda ocorreu mortalidade até as medições finais. O número de plantas observadas nestes tratamentos, no 290 mes de idade, indica estabilização da densidade em torno de 6

1 CARNEIRO et al. Importância da dormência das sementes na regeneração da bracatinga. 1980. (não publicado). 
a 7 mil plantas/ha. Deste modo, se aplicado um desbaste seletivo para densidades próximas a estas, principalmente em bracatingais demasiadamente densos, poderá haver redução da mortalidade e concentração dos fatores de crescimento em um número menor de plantas, mais vigorosas. Todavia, com os dados obtidos (medições até o 290 mes de idade ) não se pode precisar a intensidade de desbaste e o momento de realizá-lo.

\subsection{Crescimento da bracatinga}

\subsubsection{Altura e diâmetro}

Até quinze meses após a implantação, a associação com milho e feijão af etou signif icativamente a al tura da bracatinga (Tabela 13). Todavia, a partir do 20 ํôs de idade evidenciou-se tendência de equiparação dos sistemas, consorciados ou não, confirmada na última medição, aos 29 meses de idade. Quanto ao diâmetro, os sistemas SFM1 e SFM2, desbastados e não consorciados, mantiveram superioridade sobre os outros até o final das avaliações (Tabela 14).

O consórcio tende a reduzir o crescimento inicial da bracatinga em altura e diâmetro, independentemente da densidade das plantas das espécies agrícolas. Não foram observadas diferenças significativas em altura e diâmetro entre os tratamentos consorciados com diferentes densidades de mitho (Tabelas 13 e 14). Comportamento seme lhante foi observado por diversos autores, estudando dif erentes espécies arbóreas helióf ilas consorciadas com mitho: GURGEL FILHO (1962) estudando Eucalyotus alba, FERNANDEZ- VASQUEZ (1978) estudando Gmelina arborea, SCHREINER \& BAGGIO (1984) em PinUs taeda e FERNANDEZ-VASQUEZ (1987) estudando bracatinga.

A bracatinga é uma planta pioneira e, como tal, necessita de muita luz para o seu desenvolvimento (REITZ et al., 1978; KLEIN, 1981; INOUE et al., 1984; CARPANEZZI et al., 1988). Assim, há indicativos fortes que a competição por luz foi um fator importante na redução da taxa de crescimento da bracatinga nos tratamentos consorciados.

FERNANDEZ-VASQUEZ (1987) realizou medições mensais de altura e diâmetro de bracatinga; os resultados, nos dois anos de avaliação, demonstraram que o periodo de maior crescimento da bracatinga situa-se entre os 
meses de outubro a abril. Neste período, em talhões em inicio de rotação, o milho está presente e possui características fisiológicas agressivas (fotossintese do tipo C4), para competir com a bracatinga por luz, água e nutrientes. Sem dúvida, em sistemas com alta densidade de milho haverá prejuizo ao crescimento da bracatinga.

Desde a implantação, dois tratamentos destacaram-se por apresentar resultados extremos quanto ao crescimento da bracatinga: SFT e SFM1

O tratamento SFT apresentou resultados inferiores aos demais, desde as medições iniciais (Tabela 13 e 14). Forte competição interespecífica, aliada a alta densidade da espécie (Tabela 10), contribuiram de maneira significativa para as taxas reduzidas de crescimento em aitura e diâmetro, neste tratamento. Os resultados obtidos demonstram a importância das capinas no cultivo da bracatinga, especialmente na fase de implantação da cultura. A competição exercida pelas plantas invasoras e a necessidade de capinas em cultivos florestais, inclusive para condução de bracatingais, são amplamente difundidas (COSTA et al., 1954; VIANNA, 1954; ANDRADE, 1961 ; SIMÕES et al., 1976; CARPANEZZI, 1989).

$\mathrm{Na}$ Costa Rica, um ensaio de espaçamentos de bracatinga $\left(0,25 \mathrm{~m}^{2}\right.$ a $8 \mathrm{~m}^{2}$ por planta) demonstrou crescimentos individuais maiores de altura e diâmetro nos menores espaçamentos, aos 18 meses de idade (CATIE, 1986a). Tal tendência foi contrariada pelos resultados obtidos no presente trabalho onde, aos 29 meses, o maior crescimento em altura e diâmetro foi obtido no tratamento com menor lotaçäo de plantas (tratamento SFM2, Tabelas 13 e 14).

Os tratamentos SFM1 e SFM2 apresentaram maior crescimento em altura e diâmetro. Este resultado demonstra a importância da capina para a redução da competição inicial das invasoras e para o raleio inicial de plântulas de bracatinga. Outra prática que contribuíu de maneira significativa para aumentar o crescimento foi o desbaste seletivo, aos 4 meses de idade, reduzindo a densidade.

\subsubsection{Volume individual}

De um modo geral, em sistemas com densidade arbórea igual ou semelhante, houve tendência de a presença de cultivos agricolas reduzir o crescimento 
de plantas de bracatinga (Tabela 16). Resultados similares foram obtidos por GURGEL FILHO (1962), FERNANDEZ-VASQUEZ (1978) e SCHREINER \& BAGGIO (1984)

Entre os sistemas agroflorestais, SAT e SAM, observou-se que a maior densidade do milho pre judicou o desenvolvimento da bracatinga (Tabela 16). Atribui-se o menor crescimento da bracatinga ‘a competição por fatores de crescimento exercida pelos cultivos associados. Conceitualmente, SANCHEZ (1981) e COPIJN (1988) apontam, entre as limitações ecológicas na consociação de culturas, a competição por água, luz e nutrientes. Em cultivos associados, se os recursos para o crescimento das espécies são limitados, uma espécie pode ser mais apta do que a(s) outra (s) para obtê-los; assim, a espécie menos apta terá menor produção em consequência da competição (GLEISSMAN, 1986). O milho tem crescimento mais rápido provocando, desta forma, sombreamento sobre a bracatinga, com consequente redução de seu crescimento.

Os resultados apresentados pelos sistemas consorciados demonstram que a distribuição espacial das plantas agricolas, fator associado ‘a competição por luz, contribuiu para o menor crescimento da bracatinga no tratamento SAM. Segundo observações de campo, na encosta onde instalou-se o experimento, 0 milho plantado em linhas, como no tratamento $\operatorname{SAM}(1,60 \times 0,25 \mathrm{~m})$, provocou sombreamento sobre a bracatinga bem maior do que o milho plantado em espaçamento amplo na linha $(1,20 \times 0,60 \mathrm{~m}$ ) como no tratamento SAT (BAGGIO et al., 1986; CARPANEZZI et al., 1988). Justifica-se, deste modo, a adoção de espaçamentos amplos para o milho, utilizados no sistema tradicional de cultivo de bracatinga, numa região cujo relevo caracteriza-se por ser ondulado e fortemente ondulado, facilitando o sobreamento da bracatinga pelo milho. Deve-se levar em consideração que uma cultivar local de milho branco, de porte alto, é comumente utilizada no sistema tradicional (CARPANEZZI, 1989).

A adubação com fósforo nas culturas agrícolas não teve efeito sobre o crescimento da bracatinga: o tratamento SAM foi adubado e nele a bracatinga apresentou crescimento diamétrico igual ao SAT, não adubado. Provavelmente, a ineficácia da adubação decorreu da colocação do adubo somente na camada superficial do solo, onde o teor de fósforo já era mais elevado do que nas camadas inferiores (Tabela 5) e, supostamente nada ou pouco limitante ao crescimento da bracatinga. 
Quando não consorciada, a bracatinga apresentou maior crescimento individual nas densidades menores. O desbaste aos quatro meses, para um número de plantas de bracatinga próximo ao "stand" final do ciclo de corte ( 7 anos), resultou em maior crescimento individual das plantas (Tabela 16, tratamento SFM2). Deste modo, se a mortalidade neste tratamento não for acentuada nos próximos anos, rendimentos superiores poderão ser obtidos com uma redução drástica de plantas no primeiro ano.

Mais uma vez, os resultados obtidos no tratamento SFT demonstram os baixos rendimentos obtidos quando não são realizadas capinas de limpeza. Neste sistema, o crescimento volumétrico da bracat inga apresentou resultados inferiores aos demais. Em concordância, CINGAIPE (1985), estudando o crescimento inicial de Eucalyptus camaldulensis em consórcio com mi tho e fei jão separadamente, com limpeza total da área e somente coroamento das árvores, obteve maior crescimento em al tura e diâmetro do eucalipto nos tratamentos com limpeza total. Resultados semelhantes foram obtidos por PIENAAR et al. (1983) em Pinus elliottii, de 9 a 15 anos de idade, na Flórida: a eliminação total do sub-bosque provocou aumentos de 7 e $15 \%$ no volume por hectare após dois e quatro anos, respectivamente.

\subsubsection{Volume por hectare até os 29 meses de idade}

A produção volumétrica obtida aos 29 meses de idade, nos diversos sistemas, foi muito afetada pela densidade da bracatinga (Tabela 17). Infere-se, ainda, que sistemas com densidades semethantes de bracatinga tiveram rendimentos menores quando consorciados com cultivos agrícolas.

A Figura 5 ilustra queda brusca da população de plantas de bracatinga no primeiro ano, especialmente no sistema com densidade populacional elevada, não desbastado. Após o. primeiro ano ainda registrou-se mortalidade, porém a evolução da curva foi mais lenta. Um dos mecanismos reguladores de populações estudados por SILVERTOWN (1987) é a mortalidade dependente da densidade. A mortalidade precoce da bracatinga parece estar associada à alta densidade, em razão da competição intraespecifica por fatores de crescimento, levando 'a morte as árvores dominadas. 
No tratamento SFM2, intensamente desbastado (intensidade de desbaste 57\%, Tabela 10 ), a mortalidade percentual igualou-se a dos tratamentos com menor intensidade de desbaste e com densidade pós-desbaste muito maiores (Tabela 12); em valores absolutos, todavia, a mortalidade do tratamento SFM2 é, claramente, inferior. Também CARPANEZZl et al. (1988) registraram, em medições entre 0 primeiro e o quarto ano, em bracatingais do sistema tradicional, mortalidade dependente de densidade, expressa em número de plantas por hectare. Dados de plantios do mesmo autor e de FERNANDEZ-VASQUEZ (1987) reforçam a opinião que a mortalidade precoce da bracatinga no sistema tradicional é, principalmente, determinada por densidade excessiva.

Por outro lado, é esperado que a bracatinga, na qualidade de espécie pioneira, tenha mortalidade precoce (Tabela 1), sendo substituida, gradativamente, por espécies caracteristicas de etapas sucessionais mais avançadas. Na Tabela 2, comprova-se a redução da densidade da bracatinga com a idade, em povoamentos de regeneração natural, e o aumento paralelo da densidade de outras espécies arbóreas. Assim, a mortalidade precoce da bracatinga parece estar associada a dois fatôres: à densidade e à sua condição de espécie pioneira.

Os tratamentos SFT e SFM2 possuem densidades em extremos opostos (Tabela 12) mas apresentaram, aos 29 meses, volumes por área equivalentes (Tabela 17), resultantes da correlação inversa observada entre número de plantas por hectare e diâmetro. Todavia, deve-se esperar, até o momento de corte, maior mortal idade no tratamento SFT.

CARPANEZZl et al. (1988), considerando dados de diferentes fontes, verif icou que a densidade populacional em bracatingais no sistema tradicional, na idade de corte ( 7 a 8 anos), situa-se em uma faixa bem definida, entre 1400 a 3000 plantas/ha. Os resultados obtidos nas avaliaçōes aos 29 meses apresentaram densidades elevadas, entre 5000 a 13000 plantas/ha (Tabela 12); consequentemente deve-se esperar, ainda, alta mortalidade até o corte. No tratamento SFM2, espera-se mortalidade menor em valor absoluto, como tem ocorrido até o momento, associada ao maior crescimento volumétrico individual (Tabelas 12 e 16). Isto, todavia, não garante maior produtividade por área, a qual depende também da densidade. 
A produção volumétrica obtida no tratamento SFM1, com densidade populacional intermediária, aproximadamente 7000 plantas/ha aos 29 meses de idade, foi significativamente maior que no tratamento SFM2, sem dúvida devido ao maior número de plantas.

Nas avaliações iniciais, o tratamento SFM1 era superior aos demais em volume por área (Tabela 17), contudo igualou-se ao SAT e ao SAM nas avaliações finais (20 e 29 meses). Estes resultados fazem supor que, no inicio da rotação, a competição exercida pelas culturas agricolas, principalmente o milho, l imita o crescimento da bracatinga, a qual retoma o crescimento após a retirada das culturas anuais (Figura 6 ).

\subsubsection{Volume previsto até os 7 anos}

Na equação de volume desenvolvida, os ajustes apresentaram coeficientes de correlação baixos quando foram pareadas idades distantes. Os ajustes foram mais precisos à medida que as idades pareadas eram mais próximas, até mesmo para idades menores (Tabela 18). Baixas correlações de idades jovens com idades medianas e com idades avançadas também foram obtidas por GUIMARÃES (1982). Isto é atribuido ao fato de que, na fase de estabelecimento de plantios florestais, fatores adversos como: temperatura, geadas, déficit hídrico, pragas, doenças e competições intra e interespecífica podem afetar a produção esperada. Assim, as predições volumétricas para bracatinga foram mais precisas a partir do terceiro ano (Tabela 18).

A produtividade de bracatingais tradicionais, observada por CAMPOS et al. (1986), registra valores no início da rotação (2 para 3 anos) próximos ao obtido nos tratamento SFT, o qual apresentou os menores rendimentos entre os sistemas estudados. Entretanto, entre o $3^{0}$ e $4^{0}$ ano e entre o $6^{\circ}$ e $7^{0}$ ano, os aumentos registrados por CAMPOS et al. (1986) foram superiores aos rendimentos obtidos em todos os sistemas estudados neste trabalho. Como consequência, a produtividade no final da rotação obtida por CAMPOS et al. (1986) supera a média regional anual de 12,5 $\mathrm{m}^{3} /$ ha relatada por CARPANEZZI et al. (1988), a qual se aproxima dos valores obtidos neste trabalho. Provavelmente, esta distorção está associada aos bracatingais 
amostrados por CAMPOS et al. (1986)(um de cada idade) e ao processo de determinação de seus volumes.

Produtividades de bracatinga, muito superiores às dos sistemas estudados, foram relatadas por PICADO (1985), CARPANEZZI et al.(1988), CATIE (1991), VOLKART et al.(1991) e BAGGIO et al. (1992), sempre associadas a condições ambientais e de cultivo mais favoráveis.

No sistema tradicional de cultivo, não é corrente o uso de adubação da espécie florestal ou dos cultivos agrícolas. A queima dos residuos de exploração propicia mineralização rápida de parte considerável dos nutrientes e tem o efeito imediato de aumentar a fertilidade química do solo, principalmente na camada superficial. Assim, observa-se na Tabela 5 , especialmente até $10 \mathrm{~cm}$ de profundidade, teores maiores de cálcio, magnésio, potássio e fósforo com consequentes aumento de $\mathrm{pH}$ e redução do alumínio.

A médio e longo prazos, principalmente se por rotações sucessivas, o preparo do solo para cultivo através da queima dos residuos de exploração tem consequências negativas sobre a produtividade do sítio, devido à perda de nutrientes. POGGIANI et al. (1983) constataram, aos 47 meses, redução de $30 \%$ em volume de madeira produzida em brotações de Eucalyptus grandis, em áreas de corte raso onde houve queima dos residuos da exploração. Resultados semelhantes foram obtidos por MALUF et al. ${ }^{2}$ (1994) que demonstraram redução de $11 \%$ no crescimento em volume cilindrico de Eucalyptus camaldulensis, aos 37 meses, em área de cerrado preparada com queima de resíduos, comparativamente à área sem queima.

Segundo LAURENT et al. (1990a), $71 \%$ dos bracatingais da Região Metropolitana de Curitiba tem mais de três rotações, com preparo do terreno por que ima em cada uma delas, resultando em empobrecimento progressivo do sitio. A exportação de nutrientes é aumentada pelo relevo íngreme (que favorece 0 escorrimento superficial) e pelas colheitas agrícolas no início de cada rotação. A condução rudimentar da bracatinga, reduzida às capinas da fase agrícola, é ineficiente

2. MALUF, J. L. P; BARROS, N. F. de; COSTA, L. M. da \& NOVAIS, R. F. de (Universidade Federal de Viçosa, Viçosa $-M G$ ). Efeito da queimada na perda de nutrientes e seu impacto no crescimento de Euçalyptus camaldulensis na região do cerrado. (Em elaboração). 
para concentrar os fatôres de crescimento em um número adequado de árvores. Em resumo, as práticas de cultivo e manejo da bracatinga no sistema tradicional, associadas às condições de fertilidade e topografia dos terrenos, explicam suas baixas produtividades.

As predições de produção volumétrica dos diversos sistemas estudados apresentaram ganhos lineares até o 70 ano, quando situam-se entre 50 e 80 $\mathrm{m} 3 /$ ha (Figura 7). Estes resultados são compativeis com os valores de produtividade anual de bracatingais tradicionais na idade de corte apontado por CARPANEZZI et al. (1988): extremos de 7 a $15 \mathrm{~m} 3 /$ ha, média de $12,5 \mathrm{~m} 3 /$ ha. Isto pode significar que 0 sítio do experimento é de baixa produtividade ou que a equação desenvolvida subestima produtividades futuras, em certos casos. Este fato é admissivel, já que a equação foi desenvolvida com um número restrito de dados, sendo dese jável seu aperfeiçomento pela inclusão de dados de outros povoamentos, em outras idades, bem caracterizados e medidos por períodos longos. COUTO et al. (1989) também encontraram, em modelos de equações lineares simultâneas desenvolvidas para espécies de Eucalyptus, erro médio de $-3,65 \%$, significando subestimativa da produção volumétrica nesta proporção.

Os volumes obtidos através da equação confirmam as tendências, já observadas nas medições iniciais, de superioridade do tratamento SFM1 e, no outro extremo, a inferioridade do tratamento SFT.

\subsection{Produção agrícola}

A produtividade de milho foi, estatísticamente, superior quando associado com feijão, sem bracatinga (Tabela 21, tratamento CA). A superioridade resulta da maior densidade de plantas. Os rendimentos obtidos neste tratamento enquadram-se na produtividade anual média registrada para a região, onde cultivos de milho consorciado com fei jão tem média histórica entre 1200 a $1600 \mathrm{Kg} / \mathrm{ha}$ (IAPAR, 1978; IAPAR, 1982; CARPANEZZI, 1989; LAURENT et al., 1990a).

Não houve, entre os tratamentos consorciados com bracatinga (SAT e SAM, Tabela 21), diferenças estatisticas de produtividade para o milho. A produtividade média obtida foi inferior à média regional para o milho consorciado com feijão, sem bracatinga. 
Resultados de LAURENT et al. (1990b), em quatro experimentos de bracatinga consorciada com mitho e feijão, em Bocaiúva do Sul - PR, corroboram a produtividade obtida neste trabalho: o autor registra produtividade média de milho de $661 \mathrm{~kg} / \mathrm{ha}$, com extremos de 449 a $1136 \mathrm{Kg} / \mathrm{ha}$. Produtividades semelhantes, para o milho e para o feijão, foram observados por FERNANDEZ-VASQUEZ (1978), no ano de implantação da bracatinga. Também, em levantamentos locais, os produtores informam que a produtividade de milho, normalmente, é de 1600 a $1800 \mathrm{Kg} / \mathrm{ha}$ com palha, sabugo e umidade de colheita. Assim, supõe-se que a média de produtividade do mi lho para a região, no sistema tradicional, aproxime-se dos dados deste experimento. Deste modo, pode-se estabelecer, como médias aproximadas de produtividade de grãos a $13 \%$ de umidade, para o sistema tradicional, $600 \mathrm{~kg} / \mathrm{h} a$ para o milho e $180 \mathrm{Kg} / \mathrm{h}$ a para 0 feijão.

A adubação aplicada nas culturas agricolas não apresentou respostas de produtividade para o milho ou para o feijão. Também AGUIRRE (1977) não obteve aumento de produtividade para milho adubado com NPK (15-30-8), associado com eucal ipto, no sistema taungya. MUÑOZ-ALDEAN (1975), igualmente, não obteve resposta de produtividade para adubação de milho consorciado com cordia alliodora.

No presente trabalho, uma possivel explicação para a ineficácia da adubação fosfatada é que ela tenha sido aplicada em profundidade insuficiente. 0 adubo foi colocado na camada superficial do solo $(0-5 \mathrm{~cm})$, onde as quantidades de fósforo disponive is no solo (Tabela 5) já eram suficientes para o desenvolvimento da cultura e, assim, a produtividade não foi afetada pela adubação.

A adubação de cobertura com nitrogênio foi prejudicada pela estiagem que sucedeu à aplicação do adubo (Tabela 3). IAPAR (1982) relata resposta insatisfatória a adubação nitrogenada de diferentes cultivares de milho, com consequente redução na produção de grãos, devido a ocorrência de estiagem em fases criticas do desenvolvimento.

Não houve diferenças significativas de produtividade de feijão, nos diversos sistemas estudados (Tabela 21). Todavia, nos sistemas em que foram cultivadas duas linhas de feijão entre as linhas de milho, a produção obtida foi $80 \%$ 
superior ao tratamento SAT, com uma linha de feijão. O espaçamento utilizado para 0 milho no sistema tradicional permite o cultivo de duas linhas de fei jão, aumentando sua produtividade.

Na Região Metropolitana de Curitiba os agricultores, normalmente, cultivam a bracatinga em associação com mitho e fei jão. A bracatinga é conduzida para altas densidades e os cultivos agricolas, proporcionalmente aos plantios solteiros, são cultivados em baixas densidades. As densidades das espécies consorciadas (bracatinga, milho e fei jão) refletem o fato que as culturas agricolas são consideradas, do ponto de vista do produtor, como uma prática importante para assegurar a implantação da bracatinga, além da produção agrícola per si. o caso extremo é que, em propriedades maiores ou concentradas na produção florestal, a fase de implantação do bracatingal é realizada por terceiros, tendo como pagamento a produção agrícola.

No sistema tradicional de cultivo da bracatinga, normalmente, não são aplicados fertilizantes. Entretanto, em cada rotação uma grande quantidade de nutrientes, ainda não quantificada, é exportada tanto pelas culturas agrícolas como pela lenha de bracatinga e pela queima de residuos. Nas condições sócio-econômicas e culturais do sistema tradicional, a adubação das culturas agricolas, com possivel aproveitamento residual pelas árvores, parece ser a possibilidade mais plausivel para melhorar o balanço de nutrientes, e consequentemente, as produções agricola e florestal. Todavia, a adubação e outras possiveis melhorias do sistema, como adensamento e disposição espacial das culturas agrícolas, são fortemente ameaçadas por um fator regional de risco: a ocorrência de veranicos.

Estas observações levam a considerar como importantes as inovações técnicas que sup lantem os efeitos dos veranicos sobre as plantas agricolas, por exemplo o desenvolvimento e introdução de cultivares de mitho mais tolerantes à períodos de estiagem.

\subsection{Avaliação econômica}

Entre os sistemas estudados, o que apresentou o maior VLP à qualquer taxa de desconto estudada foi o SFM1, seguido pelos tratamentos SAT, SAM e CA. Os tratamentos SFT e SFM2 apresentaram os menores valores de VLP. Entretanto, 
todos os sistemas estudados podem ser considerados rentáveis por apresentarem VLP positivo.

O sistema não consorciado (tratamento SFM1) apresentou VLP superior aos sistemas consorciados (Tabela 22). Este resultado indica que, embora os sistemas com cultivos agricolas associados 'a bracatinga forneçam uma receita no primeiro ano, eles não remuneram o capital empregado tanto quanto o cultivo da bracatinga sem consórcio. As produtividades da bracatinga (volume/ha) e do milho e feijão ( $\mathrm{Kg} / \mathrm{ha}$ ), obtidas nos tratamentos consorciados, foram inferiores às obtidas nos tratamentos não consorciados ref letindo, desta forma, sobre os resultados econômicos.

O tratamento SFM1 (plantio florestal puro) indica a direção do aumento de produtividade florestal e, principalmente, de rentabilidade econômica. Todavia, existe um sistema de cultivo de bracatinga já estabelecido, o sistema agroflorestal tradicional. Nele, a produção florestal coexiste com a produção agrícola, indispensável para alimentação humana e animal na propriedade. Do ponto de vista do produtor, conforme atesta LAURENT (1990b), a bracatinga tem uma importância secundária, em termos de renda econômica, embora seu papel na propriedade constitua uma "poupança verde". Estas observações conf irmam a importância social e econômica dos cultivos agricolas que, ob jetivamente, representam a alimentação familiar direta e indireta. Assim, pressupõe-se que o plane jamento empírico das propriedades, em talhões de 2 a 4 hectares para cultivos anuais de bracatinga (CARPANEZZl et al., 1988) tem, como finalidade principal, a liberação de áreas em pousio para cultivos agrícolas, que suprem as necessidades alimentares na propriedade.

Entre os tratamentos consorciados (SAT e SAM), o sistema agrof lorestal tradicional (SAT) apresentou VLP superior em qualquer taxa de desconto (Tabela 22). A aplicação de recursos em adubo não reverteu em acréscimo de produtividade, resultando em menor retorno de capital no tratamento SAM.

O cultivo de bracatinga não consorciada, em densidades extremas, nos limites superior e inferior (SFT e SFM2), apresentou baixa remuneração de capital, comparativamente aos demais sistemas estudados, quando comparados pelo critério VLP. 
No caso de densidades elevadas (tratamento SFT), o cultivo da bracatinga foi realizado sem tratos culturais e, portanto, não houve investimento em mão-de-obra para condução da cultura. Todavia, os rendimentos foram inferiores a todos os demais sistemas estudados, com exceção do tratamento SFM2. Os resultados de VLP obtidos neste tratamento indicam que, embora com baixo rendimento em lenha, o sistema SFT é rentável em virtude do baixo custo de implantação. Na Tabela 23 observa-se que o sistema apresenta retorno significativo para cada unidade de capital empregado (RBC=2,14 e TIR $=56,75 \%$ ).

No sistema mane jado para baixas densidades de bracatinga (tratamento SFM2), o ganho em volume por árvore foi superior aos sistemas que sofreram desbastes menores (Tabelas 10 e 17). Entretanto, a produtividade por área foi menor resultando, assim, menor rendimento econômico (Tabelas 22 e 23). Este tratamento foi, entre todos, o que apresentou menor VLP em qualquer taxa de desconto. Sua RBC (Tabela 23) foi inferior aos demais tratamentos, superando os tratamentos CA e SAM. O tratamento CA tem valor inferior, em função dos altos custos anuais de implantação e manutenção.

O tratamento CA apresentou valores de VLP satisfatórios. Todavia, a superioridade econômica do sistema exclusivamente agrícola é muito vulnerável a fatores de risco como veranicos, doenças etc., e à redução progressiva da fertilidade do solo que ocorre ao eliminar-se o pousio. Os resultados econômicos obtidos neste tratamento baseiam-se na produtividade do primeiro ano, também adotada para os seguintes, o que não ref lete a realidade. De um modo geral e especif icamente neste trabalho, os terrenos onde a bracatinga é cultivada são ingremes e com pousio de 7-8 anos, o que contribui para um melhor rendimento das culturas agrícolas no primeiro ano. SANCHEZ (1981) atesta que na agricultura migratória, no primeiro ano de cultivo, os rendimentos das culturas agricolas são superiores, em razão do incremento de nutrientes disponiveis no solo, resultante do pousio e queima.

Por outro lado, LAURENT (1990b) atesta que na Região Metropolitana de Curitiba os pequenos e médios produtores do sistema de cultivo da bracatinga têm renda por hectare superior aos produtores que utilizam a agricultura migratória, com pousio de 3 a 30 anos e 1 a 3 ciclos agricolas entre pousios. Também GRACA et al. (1986) apontaram maior rentabilidade para bracatinga consorciada com 
mitho e feijão, não adubados, com exploração adicional da apicultura. Em estudos comparativos de sistemas de produção de bracatinga, GRAÇA \& MENDES (1987) demonstram que o cultivo de bracatinga associada com milho e feijão proporcionam maior rentabilidade econômica aos produtores.

A RBC acompanhou o critério VLP para o tratamento SFM1, o qual apresentou maior valor em todas as taxas de desconto estudadas. $O$ tratamento CA apresentou os menores valores, explicados pelos custos anuais elevados de implantação e manutenção.

Todos os sistemas estudados foram rentáveis pelo critérios TIR, com destaque para os sistemas tradicionais SFT e SAT. Neste caso, considerando a importância das culturas agrícolas para o sistema de produção da propriedade e para a ocupação da mão-de-obra regional, o sistema agroflorestal é preferivel 


\section{CONSIDERAÇÕES FINAIS}

O presente trabalho caracteriza-se por ser pioneiro em comparar experimentalmente sistemas de cultivo de bracatinga em condições reais de sua execução, isto é, em uma propriedade tipica do sistema tradicional. Por estas razões, julga-se oportuno registrar pontos considerados importantes, advindos de observações prolongadas em campo, para contribuir ao desenvolvimento de outros trabalhos semelhantes.

\subsection{Tamanho das parcelas}

Parcelas úteis de $36 \mathrm{~m}^{2}$, como as utilizadas neste trabaiho, são pequenas para estudos de produção florestal, principalmente em sistemas como os da bracatinga, onde a regeneração natural e a queima de resíduos podem provocar variações relevantes em distâncias pequenas. Todavia, como os talhões do sistema tradicional da bracatinga são muito pequenos ( 2 a 4 hectares) e em terrenos acidentados, é dificil encontrar, em um só talhão, uma superf ície suficientemente homogênea que possa abrigar várias repetições com parcelas maiores. Por isso, é conveniente considerar, em estudos similares ao presente, a possibilidade de distribuir as repetições em mais de um talhão.

\subsection{Cultivos florestal e agricola}

Do ponto de vista silvicultural, os resultados do presente trabalho são insuficientes para solucionar pontos cruciais para aumentar a produtividade da bracatinga no sistema tradicional, como as práticas para regulação da sua densidade.

No âmbito do sistema tradicional, os cultivos agricolas carecem, a rigor, de informações técnicas seguras sobre todos os aspectos, como variedades mais adaptadas às condições do sistema, distribuição espacial das plantas e adubação. Como um todo, o sistema tradicional requer uma análise integral de sua ciclagem de 
nutrientes. Mesmo com as exportações contínuas de nutrientes por rotações sucessivas, a capacidade dos terrenos em suportar uma atividade econômica tem sido mantida por décadas, embora com sinais evidentes de decréscimo de produtividade ao longo das rotações. A persistir esta tendência, pode-se prever a quebra da sustentabilidade do sistema em muitas propriedades rurais, com efeitos econômicos e sociais desastrosos.

\subsection{Aspectos econômicos}

Do is sistemas de cultivo da bracatinga destacaram-se do ponto de vista econômico, sendo cada um apropriado a um tipo particular de propriedade. Um sistema agrof lorestal, como o SAT, é adequado para propriedades com um sistema de produção (senso LAURENT, 1990a) diversificado, onde o cultivo da bracatinga interage com as demais explorações e valoriza a mão-de-obra familiar. Neste caso, as propriedades mais adequadas para abrigar o sistema são pequenas ou médias. Por outro lado, o sistema de cultivo exclusivamente florestal da bracatinga, como o tratamento SFM1, indica a direção para se obter maior produtividade florestal. Portanto, este sistema é preferivel para situações em que predomina, claramente, o interesse da produção florestal, como é o caso das indústrias de cal, verticalizadas, que possuem áreas extensas para produção de lenha de bracatinga.

\subsection{Aspectos ambientais}

O sistema tradicional da bracatinga possui aspectos ambientais marcantes, que devem ser considerados em estudos futuros sob a ótica da economia ecológica.

O sistema tradicional, ao lado de aspectos negativos como as queimadas, tem importante papel ambiental regional. Ele propicia a manutenção de cobertura arbórea, em zonas declivosas, onde os efeitos erosivos seriam agravados pela ocupação agrícola ou pecuária. Ademais, segundo CARPANEZZI et al. (1988), o sistema tradicional da bracatinga implica na coexistência de muitos talhões pequenos de diferentes idades e com sub-bosque muito diversificado, interrompidos por áreas agricolas ou de matas nativas. Esta heterogeneidade conserva, em certo grau, o equilibrio do ambiente, contribuindo para que haja poucos problemas fitossanitários no 
sistema. Este quadro, segundo CLOUT (1984), também é bastante favorável a manutenção da fauna, no âmbito dos povoamentos de produção florestal. 


\section{CONCLUSÕES}

A comparação experimental de sistemas de cultivo possibilitou as seguintes conclusões:

- dentre os sistemas exclusivamente florestais, a maior produtividade foi obtida pela realização conjunta de capinas e de redução, aos quatro meses, do número de plantas de regeneração natural para 9600 plantas/ha;

- a redução da densidade inicial de plantas de regeneração natural da bracat inga favoreceu, de modo diretamente proporcional, o crescimento individual das árvores em diâmetro e volume;

- as capinas influenciaram beneficamente o crescimento da bracatinga;

- nos sistemas agroflorestais, a presença das culturas agricolas prejudicou fortemente o crescimento da bracatinga na fase inicial, tendo havido recuperação posterior;

- a adubação das culturas agricolas não favoreceu as produtividades agrícola ou florestal;

- a produtividade agrícola foi maior nos sistemas não consorciados;

- do ponto de vista econômico, todos os sistemas foram rentáveis; 0 escalonamento de rentabilidade dos sistemas variou com o critério econômico utilizado. 


\section{REFERÊNCIAS BIBLIOGRÁFICAS}

AGBEDE, 0. 0 . Improving agroforestry in Nigéria: effect of plant density and interaction on crop production. Forest Ecology and Management, Amsterdam, 11:231239, 1985.

AGUIRRE-CASTILHO, C. Comportamiento inicial de Eucalyptus deglutaBlume, associado con mayz (sistema "taungya") en dos espaciamientos, con y sin fertilizacion. Turrialba, 1977. 130p. (Mestrado-CATIE)

ANDRADE, E. N. de 0 eucalipto. 2. ed. Jundiaí, Companhia Paulista das Estradas de Ferro, 1961, 667p.

AHRENS,S. Um modelo matemático para volumetria comercial de bracatinga (Mimosa scabrella Benth.). In: SEMINÁRIO SOBRE ATIVIDADES E PERSPECTIVAS FLORESTAIS, 4., Curitiba, 1981. Anais. Curitiba, EMBRAPA-URPFCS, 1981.p. $1-23$.

ARNOLD, J. E. M. Tree components in farming systems. Unasylva, Roma, 41(160): $35-42,1990 / 91$.

BAGGIO, J. A.; CARPANEZZI, A. A.; GRAÇA, L. R.; CECCON, E. Sistema agroflorestal tradicional da bracatinga com culturas agrícolas anuais. Boletim de Pesquisa Florestal, Curitiba, (12):73-82, 1986.

BAGGIO, A. J; GRAÇA, L. R.; OLIVEIRA, E. B. Plantio intercalar de bracatinga em áreas de cultivo agrícola. In: ENCONTRO BRASILEIRO DE ECONOMIA E PLANEJAMENTO FLORESTAL, 2., Curitiba, 1991. Anais. Colombo, EMBRAPA-CNPF, 1992. p. $297-316$. 
BANDY, D. E.; GARRITY, D. P; SANCHEZ, P. A. The worldwide problem of slasch-andburn agriculture. Agroforestry Today, Nairobi, 5(3):2-6, 1993.

BARROS, W. D. de. Plantas na conservação dos solos brasileiros. Rio de Janeiro, Ministério da Agricultura - Serviço de Informação Agrícola, 1961. 53p. (Estudos brasileiros, 14).

BRAY, R. J. \& GORHAM, E. Litter production in forest of the world. Advances in Ecological Research, London, 2:101-157, 1964.

BUDOWSKI, G. Distribution of tropical american rain forest species in the light of successional processes. Turrialba, São José, 15(1):40-42, 1965

BUDOWSKI, G. El sistema taungya, su aplicabilidad en América Tropical. Turrialba, CATIE, 1983. 8p.

CAMPOS,C. H. O.; GRAÇA, L. F; RIBAS, L. C. A produtividade do bracatingal tradicional através do tempo. Boletim de Pesquisa Florestal, Curitiba, (12):35-46, 1986.

CARPANEZZI, A. A. \& AHRENS, S. Crescimento da bracatingais de regeneração induzida, em função de densidade. Curitiba, EMBRAPA -URPFCS, 1984. 4p. (EMBRAPA-URPFCS. Pesquisa em Andamento, 24).

CARPANEZZI, A. A; IVANCHECHEN, S. L.; LISBÃO JUNIOR, L. Deposição de matéria orgânica e nutrientes por bracatinga (Mimosa scabrella Benth.). Curitiba, EMBRAPA -URPFCS, 1984. 3p. (EMBRAPA-URPFCS. Pesquisa em Andamento, 2).

CARPANEZZI,A. A. coord. Manual técnico da bracatinga. Curitiba, EMBRAPA/CNPF, 1988. 70p. (EMBRAPA-CNPF. Documentos, 20).

CARPANEZZI, O. T. B. Resultados preliminares das unidades de comprovação do sistema bracatinga. Curitiba, EMATER, 1989. 61p. (Projeto GCP/BRA/025/FRA).

CARPANEZZI, A. A. \& CARPANEZZI, O. T. B. Cultivo da bracatinga (Mimosa scabrella Bentham) no Brasil e prioridades para o seu aperfeiçoamento. In: CONGRESSO 
FloRESTAL ESTADUAL, 7., Nova Prata, 1992. Anais. Nova Prata, Imprensa Universitária, 1992, p. 640-655.

CATHARINO, E. L. M; CREST.ANA, C. S. M.; KAGEYAMA, P. Y. Biologia floral de bracatinga (Mimosa scabrellaBenth.). In: CONGRESSO NACIONAL SOBRE ESSENCIAS NATIVAS, Campos do Jordão. Silvicultura em Săo Paulo, São Paulo, 16(1):525-531, 1982.

CATIE, Turrialba, Costa Rica. Silvicultura de espécies promissoras para producion de leña en America Central: resultados de cinco años de investigacion. Turrialba, 1986a. 277p.

CATIE, Turrialba, Costa Rica. Sistemas agroforestales; principios y aplicaciones en los tropicos. San José: Organizacion para Estudios Tropicales. CATIE, 1986b.818 p.

CATIE, Turrialba, Costa Rica. Bracatinga Mimosa scabrella Benth. espécie de arbol de uso multiple en América Central. Turrialba, 1991. 49p. ( CATIE. Informe Técnico, 169).

CHIARANDA, R.; POGGIANI, F.; SIMÕES J. W. Crescimento das árvores e deposição do folhedo em talhões florestais plantados em solos alterados pela mineração do xisto. IPEF, Piracicaba, (25):25-28, 1983.

CINGAIPE, T. M. Early growth of Eucalyotus camaldulensis under agroforestry conditions at Mafiga, Morogoro, Tanzania. Forest Ecology and Management, Amsterdam, 11: 241-244, 1985.

CLOUT, M. N. Improving exotic forests for native birds, N. Z. Journal of forestry, Rotorna, 29 (2), 1984

COMBE, J. Agroforestry techniques in tropical countries: potential and limitations. Agroforestry Systems, Amsterdam, 1:13-27, 1982

COPEL - COMPANHIA DE ENERGIA ELÉTRICA DO PARANA, Curitiba, PR. Estudos da biomassa e do mercado de energéticos de produtos florestais no sudeste paranaense; relatório final. Curitiba, 1985. 149p. 
COPIJN, A. N. Agrossilvicultura sustentada por sistemas ecologicamente ef icientes. Rio de Janeiro, Fase, 1988. $51 \mathrm{p}$.

COUTINHO, L. M. O cerrado e a ecologia do fogo. Ciência Hoje, São Paulo, 12(68):22$30,1990$.

COUTO, H. T. Z. do; BASTOS, N. L. M.; LACERDA, S. J. Comparação de dois modelos de prognose de madeira de Eucalyptus para alto fuste e talhadia. IPEF, Piracicaba, $(41 / 42): 27-35,1989$.

DELEAGE, J. P.; SOUCHON, C.; TARQUINIO, T. T.; ZANONI, M. Etude de la production integreé de bois, energie et d'aliments dans l'agriculture traditionnelle au Paraná, Brasil. Paris, Université Paris-Laboratoire d'ecologie generale et appliqué. Groupe EDEN, 1984. (não publicado).

DENSLOW, J. S. Gap partioning among tropical rain forest trees. Biotropica, New Orleans, 12:47-53, 1980.

DIAS, I. de S.; KAGEYAMA, P. Y.; FONSECA, S. M. Importância das sementes na viabilidade das populações naturais de bracaatinga-Mimosa scabrella Bentham (nota prévia). In: SEMINARIO SOBRE ATIVIDADES E PERSPECTIVAS FLORESTAIS, 4. Curitiba, 1981. Anais. Curitiba, EMBRAPA-URPFCS, 1981. p. 117-122.

DISTRIBUIÇÃO DE SEMENTES E INSTRUÇÃO PARA CULTIVO DA BRACATINGA. Boletim do Ministério da Agricultura, Rio de Janeiro, 31(1):101, 1942.

DUBOIS, J. C. L. Breves considerações sobre classificação de sistemas e práticas agroflorestais. Informativo Agroflorestal REBRAF, Rio de Janeiro, $1(2 / 3): 7-9,1989$.

FERNANDEZ-VASQUEZ, S. Comportamiento inicial de Gmelina arborea Roxb. associada con mays (Zea mays) y frijol (Phaseolus vulgaris L.) en dos espaciamientos en Turrialba, Costa Rica. Turrialba, 1978. 125p.(Mestrado-CATIE).

FERNANDEZ-VASQUEZ, S. Comportamento inicial da bracatinga (Mimosa scabrella Benth.) em consórcio com milho (Zea mays L.) e feijão (Phaseolus vulgaris), com 
e sem aplicação de fertilizantes minerais em solo de campo na Região Metropolitana de Curitiba - Paraná. Curitiba, 1987. 137p. (Doutorado - UFPR).

FORESTA, H. de. Agriculture sur brúlis en fôret tropicale humide. A propos du rôle du feu dans la compétition entre espéces cultivées et espéces pionnieres. Turrialba, São José, 4(34):537-542, 1984.

GLIESSMAN, S. R. Los huertos familiares como sistemas agroforestales en el trópico húmido de México. In: BEER, J.W. \& SOMARRIBA, E. Investigacion de técnicas agroforestales tradicionales. Turrialba, CATIE, 1981. p. 81-83.

GLIESSMAN, S. R. Plant interactions in multiple cropping systems. In: FRANCIS, C. Multiple cropping systems. New lork, Macmillan, 1986. p. 82-95.

GOMEZ-POMPA, A. \& WIECHERS, L. Regeneración de los ecosistemas tropicales y sobtropicales. In: GOMEZ-POMPA, A et al. Regeneración de selvas. México, Editorial Continental, 1976. p. 12-30.

GRAÇA, L. R. \& MENDES, J. B. Analise econômica de sistemas de reflorestamento com bracatinga. Boletim de Pesquisa Florestal, Curitiba, (14):54-63, 1987.

GRAÇA, L. R.; RIBAS, L. C.; BAGGIO, A. J. A rentabilidade econômica da bracatinga no Paraná. Boletim de Pesquisa Florestal, Curitiba, (12):47-72, 1986.

GUIMARÃES, D. P. Predição de crescimento volumétrico de Eucalyptus grandis. Planaltina, EMBRAPA-CPAC, 1982. 11 p. (EMBRAPA-CPAC. Boletim de Pesquisa, 9)

GURGEL FILHO, O. A. Plantio de milho consorciado com eucalipto. Silvicultura em São Paulo, São Paulo, 1(1):85-102, 1962.

HOEHNE, F. C. A bracatinga ou abaracaatinga. São Paulo, Secretaria da Agricultura, Industria e Comércio do Estado de São Paulo, 1930.47p.

HOLDRIDGE, L. R. Ecologia basada en zonas de vida. San José: IICA, 1978. $216 \mathrm{p}$.

IAPAR-FUNDAÇÃO INSTITUTO AGRONÔMICO DO PARANÁ, Londrina, PR. Cartas climáticas básicas do Estado do Paraná 1978. Londrina, 1978. 38p. 
IAPAR-FUNDAÇÃO INSTITUTO AGRONÔMICO DO PARANÁ, Londrina, PR. Cartas climáticas básicas do Estado do Paraná 1978. Londrina, 1978. 38p.

IAPAR-FUNDAÇÃO INSTITUTO AGRONÔMICO DO PARANÁ, Londrina, PR. Manual agropecuário do Paraná. Londrina, 1978. 742p.

IAPAR-FUNDAÇÃO INSTITUTO AGRONÔMICO DO PARANÁ, LONDRINA, PR. O milho no Paraná. Londrina, 1982. 177p. (Circular IAPAR, 29).

ICRAF, Nairobi, Kenya. Annual report 1991. Nairobi, ICRAF, 1992. 148p.

INOUE, M. T; RODERJAN, C. V.; KUNIYOSHI, Y. S. Projeto madeira do Paraná. Curitiba, FUPEF, 1984. 260p.

KAGEYAMA, P. Y; CASTRO, C. F. A.; CARPANEZZI, A. A. Implantação de matas ciliares: estratégias para auxiliar a sucessão secundária. In: SIMPOSIO SOBRE MATA CILIAR, São Paulo, 1989. Anais. Campinas, Fundação Cargill, 1989. p. 130-143.

KING, K. F. S. The history of agroforestry, In: STEPPLER, H. A. \& NAIR, P. K. R. Agrof orestry; a decade of development. Nairobi, ICRAF, 1978. p.1-11.

KING, K. F. S. Agroforestry and the utilization of fragile ecosystems. Forest Ecology and Management, Amsterdam, 2:161-168, 1979.

KLEIN, R. M. Aspectos fitossociológicos da bracatinga (Mimosa scabrella). In: SEMINÁRIO SOBRE ATIVIDADES E PERSPECTIVAS FLORESTAIS, 4, Curitiba, 1981. Anais. Curitiba, EMBRAPA-URPFCS, 1981, p.145-148.

LANLY, J. P. Agricultura migratoria; definicion y medida de la agricultura migratória. Unasylva, Roma, 37( 147): 17-21,1985.

LAURENT, J. M. E. \& MENDONÇA, W. R. A comercialização dos produtos do sistema bracatinga na Região Metropolitana de Curitiba. Curitiba, EMATER, 1989. 46p (Estudos Florestais, 1)

LAURENT, J. M. E. Guia para diagnósticos florestais microrregionais. Curitiba, EMATER, 1990a. 71 p. (Metodologia Florestal, 1). 
LAURENT, J. M. E. Sistema agroflorestal da bracatinga na Região Metropolitana de Curitiba; contexto socio-econômico. Curitiba, EMATER, 1990b.45p.

LAURENT, J. M. E.; CAMPOS, J. B.; BITTENCOURT, S. M. Análise técnico-econômica do sistema agroflorestal da bracatinga na Região Metropolitana de Curitiba. Curitiba, EMATER, 1990a. 72p. (Estudos Florestais, 4).

LAURENT, J. M. E.;PEDREIRA, M. do R. R.; CARPANEZZI, O. T. B.; BITTENCOURT,S. M. de. Melhoramento do sistema agroflorestal da bracatinga. Curitiba, EMATER, 1990b. 106p.(Estudos Forestais, 6).

LEITÃO FILHO, H. de F.; ARANHA, C.; BACCHI, O. Plantas invasoras de culturas. Campinas, Instituto Campineiro de Ensino Agrícola, 1982. p.297-597.

LEIVA, J. M. \& BOREL, R. Analise do potencial de tres espécies forestales (Alnus acuminata, Eucalyotus globulus y Casuarina equisetifolia), en plantacion pura y en sistema taungya com maiz (Zea mays) y frijol (Phaseolus vulgaris). Revista Forestal Centroamericana, Turrialba,2(4) 1993. Information Bulletin for Developing Copuntries, Vienna, (2):21, 1993. (Resumo)

LIMA, G. S. \& BATISTA, A. C. Efeitos do fogo no ecossistema. Estudos de Biologia, Curitiba, 31:5-16, 1993.

LORENZI, H. Plantas daninhas do Brasil; terrestres aquáticas, parasitas, tóxicas e medicinais. 2. ed. Nova Odessa, Editora Plantarum, 1991. 440p.

LUNDGREN, B. O. \& RAINTREE, J. B. Sustained agroforestry. In: NESTEL, B. Agricultural research for development: potentials and challenges in Asia. S.1., ISNAR, 1982. p. 37-49.

LUKEN, J. O. Directing ecological succession. New York, Chapman \& Hall, 1991. $251 p$.

MAACK, R. Geografia física do Estado do Paraná. Curitiba, M. Roesner, 1968. $350 \mathrm{p}$. 
MACDICKEN, K. G. Agroforestry management in the humid tropics. In: MACDICKEN,K. G. \& VERGARA, N. T., Agrof orestry: classification and managment, New York, John Wiley, 1990. p.98-149.

MACDICKEN, K. G.; VERGARA, N. T. Introduction to agroforestry. In: MACDICKEN, K. G. \& VERGARA, N. T. Agrof orestry: classif ication and management. New York, John Wiley, 1990. p. 6-30.

MARTINEZ-RAMOS, M. Claros, ciclos vitales de los arboles tropicales y regeneración natural de las selvas altas perenifolias. In: GOMEZ-POMPA, A. \& DEL AMO, R. S., Investigaciones sobre la regeneración de selvas altas en Vera Cruz. México, Editorial Continental, 1985. p. 191-239.

MARTINS, R. Livro das árvores do Paraná. Curitiba, Diretório Regional de Geografia do Estado do Paraná, 1944.274p.

MUÑOZ-ALDEAN, M. Comportamiento inicial del laurel Cordia alliodora (Ruiz y Pav.) Oken plantado em asocio con mayz (Zea mays) bajo dos niveles de fertilizacion. Turrialba, 1975. 78p. (Mestrado - CATIE).

NAIR, P. K. R. Agroforestry defined. In: NAIR, P. K. R. Agroforestry systems in the tropics. Dordrecht, Kluwer Academic Publishers, 1979. p. 13-18.

NAIR, P. K. R. Classification of agroforestry systems. Agroforestry systems, Amsterdam,3:97-128, 1985.

NEME, M. Cultura da bracatinga. Chácaras e Quintais, 44 (9):307-308, 1931.

NOWACKI, M. J. A "bracatinga" e os fungos apodrecedores de sua madeira. In: CONGRESSO FLORESTAL BRASILEIRO, 1., Curitiba. 1953. Anais. Rio de Janeiro, Instituto Nacional do Pinho, 1954. p. 91-94.

ODUOL, P. A. The Shamba system:an indegenous system of food production from forest areas in Kenya. Agroforestry Systems, Amsterdam, 4:365-373, 1986. 
OLDEMAN, R. A. A. Architeture and energy exchange of dicotiledonaus tree in the forest. In: TOMLINSON, P. B. \& ZIMMERMANN, M. H. Tropical trees as living systems. Cambridge, Cambridge University. Press., 1978. p. 535-560.

OSTA,A. J.; LEÃO, O. de A. C.; VAISTMAN, J.; SANTOS, E.; MEURER, D. de M. Calendário agrícola do Brasil; Paraná. Rio de Jane iro: Ministério da Agricultura. Serviço de Informação Agricola, 1954. 68p.

PARANÁ. Secretaria de Estado do Plane jamento. Departamento Estadual de Estatistica. Anuário estatístico do Paraná. Curitiba, 1977. 190p.

PICADO, W. Mimosa scabrella espécie com potencial para sombra y produccion de leña em caf etales de Costa Rica In: SIMPOSIO SOBRE TECNICAS DE PRODUCCION DE LEÑA EM FINCAS PEQUENAAS Y RECUPERACION DE SITIOS DEGRADADOS POR MEDIO DE SILVICULTURA INTENSIVA, Turrialba, 1985. Actas. Turrialba, CATIE, 1985. p.227-239.

PIENAAR, L. V; RHENEY, J. W.; SHIVER, B. D. Response to control of competing vegetation in site prepared slash pine plantation. Southern Journal of Applied Forestry, Bethesda, 7(1):38-45, 1983.

POGGIANI, F; REZENDE, G. C.; SUITER FILHO, W. Efeitos do fogo na brotação e crescimento de Eucalyptus grandis após o corte raso e alterações nas propriedades do solo. IPEF, Piracicaba, (24):33-42, 1983.

POGGIANI, F. \& MONTEIRO,C.C. Efeito da implantação de maciços florestais puros na reabili tação do solo degradado pela mineração de xisto betuminoso. In: CONGRESSO FLORESTAL BRASILEIRO, 6, Campos do Jordão, 1990. Anais. São Paulo, SBS, 1990. p. $275-280$.

RAINTREE, J. B. Theory and practice of agroforestry diagnosis and design, In: MACDICKEN, K. G. \& VERGARA, N. T., Agroforestry: classification and management. New York, John Wiley, 1990. p. 58-97.

RAINTREE J. B \& WARNER, K. Agroforestry pathways for the intensif ication of shif ting cultivation. Agroforestry Systems, Amsterdam, 4(1):39-54, 1986. 
REITZ, R; KLEIN, R. M. \& REIS, A. Projeto madeira de Santa Catarina. Itajaí, Herbario Barbosa Rodrigues, 1978, 320p

REZENDE,G. C. de \& FONSECA, E. de P. Implantação da cultura de eucalipto. Informe Agropecuário, Belo Horizonte, 12 (141):20-24, 1986.

ROTH, P. S. O efeito do fogo sobre a quebra de dormência em sementes de bracaat inga (Mimosa bracaatinga Hoenne). Piracicaba, IPEF, 1982.7p. (IPEF. Circular Técnica, 143).

ROTTA, E. \& OLIVEIRA, Y. M. M. de. Area de distribuição natural da bracatinga (Mimosa scabrella Benth). In: SEMINARIO SOBRE ATIVIDADES E PERSPECTIVAS FLORESTAIS, 4., Curitiba, 1981. Anais. Curitiba, EMBRAPA-URPFCS, 1981. p. 1-23

SANCHEZ, P. A. Suelos del trópico. caracteristicas; y manejo. Turrialba, IICA, 1981. 634p.

SCHEREINER, H. G. \& BAGGIO, A. J. Culturas intercalares de milho (Zea mays L.) em reflorestamentos de Pinus taeda L. no sul do Paraná. Boletim de Pesquisa Florestal, Curitiba, (8/9):29-49, 1984.

SCHEREINER, H. G. Culturas intercalares de so ja em reflorestamentos de eucal iptos no sul sudeste do Brasil. Boletim de Pesquisa Florestal, Curitiba, (18/19):110, 1989.

SILVERTOWN, J. W. Introduction to plant population ecology 2. ed. New York, John Wiley, 1987. 229p.

SIMÕES, J. W; BRANDI, R. M.; MALINOVSKI, J. R. Formação de florestas com espécies de rápido crescimento. Brasilia, PRODEPEF, 1976. 74p.6 PNUD/FAO/IBDF/BRA-45. Série Divulgação, 6).

SOARES, R. V. Incêndios florestais; controle e uso do fogo. Curitiba, FUPEF, 1985. $213 p$. 
SOEMARWOTO, O. Homegardens: a traditional agroforestry system with a promising future. In: STEPPLER, H. A. \& NAIR, P. K. R. Agroforestry; a decade of development. Nairobi, ICRAF, 1987. p. 157-170.

STANDLEY, P. C. \& STEYERMARK, J. A. Flora of Guatemala. Fieldiana: Botany, Chicago, $24(5): 54-55,1946$.

SZOTT, L. T. \& PALM, C. A. Soil and vegetation dynamics in shifting cultivation fallows. In: SIMPOSIO DO TROPICO UMIDO, 1., Belém, 1984. Anais. Belém, EMBRAPACPATU, 1984. p. 360-379.

TEWARI, D.N. Shifting cultivation in India. Indian Forester, Nova Deli,117(2):91$104,1991$.

TORQUEBIAU, E. The agroforester's bookshelf. Agroforestry Today, Nairobi, 5 (3): 13-14, 1993 .

VAZQUEZ-YANES,C. Notas sobre la autoecologia de los arboles pioneros de rápido crecimiento de la selva tropical lluviosa. Tropical Ecology, Varanasi, 21(1): 103-112, 1980.

VECCHI, O. Bracaatinga em São Paulo. Boletim de Agricultura, São Paulo, (3/4): $171-177,1930$.

VELLOSO, H .P.; RANGEL FILHO, A. L. R. \& LIMA,J. C. A. Classificação da vegetação brasileira, adaptada a um sistema universal. Rio de Janeiro, IBGE, $1991.123 p$.

VERGARA, N.T. Sistemas agroforestales: una cartilla. Unasylva, Roma, 37(147):2228, 1985.

VIANNA, E. F. Bracatinga, essência de fácil cultivo que oferece bom rendimento em lenha. Mundo agricola, São Paulo, 3(10):46, 1954.

VINAYA RAI, R. S. \& SURESH, K. K. Agrissilvicultural studies-optimum species combination. The International Tree Crops Journal, Oxon, 5:1-8, 1988. 
VOLKART, C. M; TRUMPLER, M. G. P. de; FRIEDL, R. A; LOPEZ, M. A.; LOPEZ, B. E. de. Resultados a los 4 años de un ensayo de comportamiento de espécies arbóreas y arbustivas aptas para leña en la provincia de misiones. Yvyrare tá, Misiones, 2(2):23-39, 1991.

WIERSUN, K. F. Tree gardening taungya on Java: examples of agroforestry tecniques in the humid tropics. Agroforestry Systems, Amsterdam, 1:53-70, 1982.

WHITMORE, T. C. Secondary succession from seed in tropical rain forests. Forestry Abstracts, Oxford, 44(12):767-779, 1983.

ZAVITKOVSKI J. \& NEWTON, M. Litterfall and litter accumulation in red alder stands in western oregon. Plant and Soil, Dordrecht, 35:257-268, 1971. 